\title{
Has Regulatory Capital Made Banks Safer? Skin in the Game vs Moral Hazard
}

\author{
Ernest Dautović * \\ University of Lausanne
}

\begin{abstract}
The paper evaluates the impact of macroprudential capital regulation on bank capital, risk taking behaviour, and solvency. The identification relies on an exogenous policy change in bank-level capital requirements across systemically important banks in Europe. A one percentage point hike in capital requirements leads to an average CET1 capital level increase of 13 percent improving their loss absorption capacity. The paper does not find evidence of costs due to reduction in assets. The paper documents robust evidence on the existence of substitution effects toward riskier assets. Consistently with arguments on agency costs and gambling for resurrection, the risk taking behavior is predominantly driven by large and less profitable banks. Large wholesale funded banks show less risk taking. Large banks relying on internal ratings based approach show also lower risk taking supporting the argument on their competitive advantage. In terms of overall impact on solvency, the higher risk taking crowds-out the positive effect of increased capital.
\end{abstract}

JEL Classification: E51, G21, O52

Keywords: capital requirements, risk-taking, moral hazard, macroprudential policy

${ }^{*}$ Faculty of Business and Economics, Internef, CH-1015 Lausanne, Switzerland. E-mail: ernest.dautovic@unil.ch

Disclaimer: The views expressed in this paper are those of the author and do not necessarily represent those of the institution with which the author is affiliated.

Acknowledgments: the author would like to thank Jonathan Bridges, Adrian Bruhin, Marco D'Errico, Antonio Di Cesare, Frank Dieric, Michal Dvořák, Elena Esposito, Harald Hau, Heleen Hofmans, Mario Jovanović, Jan Hannes Lang, Frédéric Lardo, Axel Loefler, Sergio Masciantonio, Francesco Mazzaferro, Jakob Orthacker, Tuomas Peltonen, Mara Pirovano, Antonio Sanchez, Glenn Schepens and Tibor Szendrei for valuable comments. Participants of: the ESRB expert group on structural capital buffers and the members of the ESRB Instrument Working Group, the Risk Analysis Division of the Single Supervisory Mechanism at the European Central Bank. 


\section{Non-technical summary}

The Capital Requirements Regulation (CRR) and the Capital Requirements Directive (CRD IV) introduced a new macroprudential framework transposing the Basel III agreement in the EU. The overarching goal of the new EU macroprudential regulation is to increase the loss absorption capacity of banks through the introduction of a set of systemic capital requirements. Higher capital requirement should foster the stability of the banking system and increase the resilience of banks in time of crisis allowing them to sustain the real economy.

This study estimates the effects of macroprudential capital requirements on bank capital and risk taking by looking at the reaction of EU banks to a series of increments of macroprudential capital requirements. In general, banks can increase their regulatory capital ratio in three mutually non-exclusive ways: by increasing capital, reducing the risk-weights or reducing their assets.

The sample is composed by all G-SIB and O-SIB in the EU and Norway from 2006Q1 until 2017Q3, leading to a total number of 205 banks, divided in 14 globally-systemically important banks (G-SIBs) and 191 other-systemically important banks (O-SIBs). The bank specific systemic macroprudential capital requirements are obtained from the European Systemic Risk Board (ESRB) database on macroprudential policies based on the notifications from the national authorities.

The dataset allows to capture the extent to which systemically important financial institutions are interconnected with each other and the wider financial system, and allows to isolate the effect of capital requirements from the the interaction of non-conventional monetary policy on bank risk taking.

The paper finds that the EU-wide regulatory effort to increase the resilience of the banking sector has contributed to a better capitalized European financial system: a one percentage point increase in capital requirements increases CET1 capital by an average of 13 percent. The impact is higher (17.7 percent) for banks with less than two percentage points buffer from the minimum capital requirement.

However, the significant increase in capital is accompanied with a cost: banks react to a one percentage point hike in capital requirements by increasing the average risk weights of their portfolio by 6.1 percentage points. The highest increase in risk taking is due to medium and large less profitable banks which try to achieve higher returns by substituting toward more riskier assets and compensate thus for their lower profitability. Importantly, wholesale funded banks have a lower tendency to increase their risk profile after a capital requirement increase.

The study documents that banks adopting the internal rating based (IRB) approach show a lower propensity to risk taking on their financial accounts, this evidence suggests the existence of 
a competitive advantage for IRB banks since lower risk weights imply a lower cost of compliance to higher capital requirements.

In order to estimate the overall impact on banks' solvency of the two opposing effects i.e. higher resilience achieved with increased capital versus lower resilience arising from more risk-taking - the study estimates the impact of the policy change on probabilities of default extrapolated from credit ratings. Results indicate that the positive effect of accumulating more equity capital is counterbalanced by the negative substitution effect toward more riskier assets, the net average effect on the solvency of EU banks is thus null.

The countervailing effect of risk taking on solvency raises the attention to the non-intended consequences of regulatory action, the regulatory task is not a simple one, any policy change requires a comprehensive assessment of hidden incentives behind regulatory action. 


\section{Introduction}

One of the primary objectives of central banks is to foster the stability of the banking system. Capital requirements are in general used to increase banks' resilience by requiring them to hold more capital, thereby improving loss absorption capacity during financial downturns. The policymakers' rationale for demanding more capital is to increase the skin in the game of bank equity holders, limiting risk taking behaviour while at the same time reducing the probability of insolvency and the cost of bank failure for taxpayers.

Theoretical contributions on the skin in the game argument postulate that for banks with higher capital ratios, there is an incentive by bank managers to avoid excessive risk-taking. This is because more risk increases the variance of returns which in turn can amplify the probability of significant losses on banks' equity, (Hellmann et al., 2000; Repullo and Suarez, 2004; Repullo, 2004).

At the same time, banks might increase their asset risk in response to higher capital requirements, possibly overcompensating the positive effect of the higher capital buffer. A strand of academic research argues that better capitalized banks are not necessarily taking on less risks. ${ }^{1}$ For instance, the principal-agent theory shows how the presence of imperfect information, which is endemic in complex organizations such as banks, can manifest itself in moral hazard associated with the existence of distorted incentives between the principal and the agent. ${ }^{2}$ Similarly, empirical banking literature shows how more regulated banks can have risk-taking incentives due to the negative effect of higher capital requirements on bank profits, (Koehn and Santomero, 1980; Kim and Santomero, 1988; Blum, 1999). This divergence of views raises the question as to whether and how banks' risk taking behaviour is affected by increases in regulatory capital requirements.

This paper sheds light on this question by exploiting a policy change whereby systemically important European banks were subject to variations in macroprudential capital requirements imposed by the regulator. In spirit, the study is closely related to the earlier empirical studies on risk-taking and risk sensitive capital requirements such as Shrieves and Dahl (1992) or Jacques and Nigro (1997). The present study contributes to this literature by applying modern econometric tools and using a policy shock as an exogenous source of variation to bank capital for the identification of the causal response to higher capital requirements.

\footnotetext{
${ }^{1}$ In this paper, risk-taking behaviour is intended as exposure risk of the portfolio of banks' assets, measured as the ratio of risk-weighted assets over total assets.

${ }^{2}$ Several strands of literature have shown the consequences of the principal-agent asymmetric information problem. Academic contributions range from the fields of economics Stiglitz and Weiss (1981), finance Acharya and Naqvi (2012), managerial Wiseman and Gomez-Mejia (1998), corporate finance (Ross, 1973; Bolton et al., 2015 ) to law and banking regulation Alexander (2006). This literature illustrates how within a principal-agent relationship the presence of incomplete information and misaligned incentives can induce managers to take on excessive risk and how regulation can help to limit this inefficiency.
} 
The newly introduced macroprudential capital requirements have been phased-in, in successive steps across the 28 European Union (EU) countries starting in 2014. They apply to parents and subsidiaries of systemically important banks. ${ }^{3}$ The focus on systemically important banks is important since financial stability concerns arise predominantly from risky activities undertaken by those institutions. EU macroprudential regulation empowers national authorities to set individual bank-level capital requirements for systemic risk, these are introduced at different times across EU countries thereby allowing for both cross-country and cross-bank comparison. The staggered policy implementation across borders and time fosters the opportunity for a research design based on a quasi-experiment provided that i) the policy change is exogenous, ii) there are no spillovers across borders, iii) banks do not anticipate the change, i.e. the common trend assumption holds.

The exogeneity of the policy change may not be warranted because capital requirements are introduced for each bank individually by its own prudential authority. This leaves discretion to national regulators and could cause the introduction of these requirements to be endogenous if the Member State behaves strategically and wants to protect domestic banks. Nevertheless, this concern is mitigated by several provisions enshrined in EU banking regulation which are specifically aimed at eliminating national biases with respect to macroprudential risks.

The first provision establishes that four different EU institutions are overseeing the implementation of macroprudential buffers across the EU, namely the ESRB, the EU Commission, the EBA and the ECB. ${ }^{4}$

In addition, the ESRB ha the mandate to identify and monitor systemic risk in the EU. To preserve financial stability, the ESRB can issue public warnings for Member States where identified systemic risks are deemed to be significant and can release recommendations to Member States requesting remedial action in response to non addressed risks. Moreover, the ESRB can issue confidential warnings to the Heads of States at the EU Council and must monitor the follow-up to issued warnings and recommendations. ${ }^{5}$

The third provision is the ECB top-up power, this guarantees that there is no inaction bias toward strategically important domestic banks, that is the ECB can apply higher macroprudential capital requirement than the one established by the national competent authorities.

\footnotetext{
${ }^{3}$ As of 2017Q3, Global and Other Systemically Important Banks (G-SIBs and O-SIBs) in the EU are 204 financial credit institutions. They represent $86 \%$ of total consolidated assets of EU banks in 2016 according to consolidated balance sheet statistics, see ECB source. The sample composition of SIBs may vary from year to year due to new banks being designated as O-SIB, or old banks not satisfying any more the requirements to be designated as O-SIBs. See European Banking Authority Guidelines on O-SIB.

${ }^{4}$ See fot instance, Article 131(7) of the Capital requirements Directive IV (CRDIV) which states that before setting or resetting an O-SIB buffer, the competent authority shall notify the Commission, the ESRB, EBA, and the competent microprudential supervisors of the Member States concerned one month before the publication of the decision.

${ }^{5}$ For more information on ESRB's tasks and powers see the related ESRB regulation.
} 
At the same time, regulation guarantees that foreign subsidiaries are treated fairly and equally without being affected by protectionist measures. Acting on a proposal by the EU Commission, the EU Council of ministries has the power to reject the proposed national macroprudential measure. ${ }^{6}$ For Euro Area banks, any measure requires the approval of the ECB Governing Council. ${ }^{7}$ With a further aim of fostering consistency, the ECB has also developed a framework to provide a minimum common floor when calibrating systemic capital requirements applied at the national level. ${ }^{8}$ By providing a minimum floor, the ECB reduces national discretion in calibration of the capital instrument and provides the basis of a discussion between the ECB and national authorities on the overall assessment of the appropriateness of a macroprudential stance.

The validity of the research method could be questioned if large banks shift their assets across borders to branches or subsidiaries in order to conduct regulatory arbitrage. In this case, the existence of spillover effects may produce biased estimates. However also this concern is mitigated by regulation which envisages the possibility of reciprocation. This grants the power to a Member State to request a countervailing capital increase to exposures of foreign branches within its borders, or directly across borders when risks of spillover are deemed significant. Reciprocation should ultimately ensure the reduction of the incentive to search for regulatory arbitrage and the enforcement of a level playing field among parents, subsidiaries, and branches within and across the borders. ${ }^{9}$ Furthermore, the study addresses the concerns of spillovers by using consolidated financial accounts which eliminate the possibility of spillovers since the unit of measurement is the consolidated banking group. The use of consolidated data is also required since macroprudential capital requirements are levied at a group consolidated level.

The reciprocation framework, in conjunction with other provisions established in the EU banking regulation, alleviate to a great extent the concerns on the validity of the research method due to endogeneity stemming from national considerations.

Regarding the existence of anticipation effects, Section 7 presents two standard tests of the common trend assumption and an additional test of the anticipation behavior stemming from announcement effects. The first test of the common trend assumption controls for banklevel trends in the regression similar to Wolfers (2006), the second inspects the existence of

\footnotetext{
${ }^{6}$ This is in accordance with Article 291 of the Treaty on the Functioning of the European Union (TFEU).

${ }^{7}$ For the ECB top-up power and the scrutiny of the ECB on national macroprudential measures see Articles 5(1) and 5(2) of the Single Supervisory Mechanism Regulation.

${ }^{8}$ See ECB floor methodology for setting the capital buffer for an identified Other Systemically Important Institution (O-SII)

${ }^{9}$ The reciprocity framework is codified in two main documents: (i)Recommendation of the ESRB/2015/2; (ii) Article 5 of Decision ESRB/2015/4. For a detailed account of the reciprocation framework in the EU consult the dedicated ESRB web page on reciprocation, and Chapter 11 of the ESRB Handbook on operationalising macroprudential policy. In this context, the ESRB has an important coordination role in assessing measures, discussing cross-border effects, and recommending mitigating measures, including reciprocity.
} 
anticipatory behaviour which would invalidate the common trend assumption. The test on the anticipation effect is akin to Alpert (2016) and investigates the presence of announcement effects of the policy.

The econometric specification relies on a panel of bank-level balance sheet data and a regression difference-in-difference design. A cross-country bank-level panel controls for time varying macroeconomic variation absorbed by country-time dummies. In contrast to single country bank-level studies, the setting presented in this paper can increase the external validity of the results. In comparison to cross-country macroeconomic papers, it improves on the granularity of available data which fosters the study of heterogeneous effects and bank-level drivers describing the reaction to higher capital requirements. The use of the granular banklevel database allows to measure banks interconnectedness with the financial system through interbank lending and OTC derivatives. This is an essential feature for delivering unbiased estimates since the calibration of capital requirements is correlated with indicators of the banks' interconnectedness and complexity. In addition, monetary policy, and in particular quantitative easing, which may influence banks ability to raise capital by providing more stable sources of funding is controlled for by including cash held at Central Banks. Finally, this study provides a detailed account for heterogeneity in terms of size, profitability, and funding sources.

The paper finds that the EU-wide regulatory effort to increase the resilience of the banking sector has contributed to a better capitalized European financial system. In the baseline specification, a one percentage point increase in capital requirements increases CET1 capital by an average of 13 percent. The impact is higher (17.7 percent) for banks with a buffer lower than two percentage points from the minimum capital requirement and for which the policy tightening is more binding. When requirements are relaxed in a downturn, the increase in highest quality CET1 capital can help the banks in supplying credit acting counter-cyclically to sustain economic growth in bad times.

However, the significant increase in capital is accompanied with a cost: banks react to a one percentage point hike in capital requirements by increasing the average risk weights of their portfolio by 6.1 percentage points. The impact is attenuated for small banks 4.3 percentage points, however medium (7.3 p.p.) and large (9.6 p.p.) systemically important banks have a significantly higher risk taking behavior.

In order to estimate the overall impact on banks' solvency of the two opposing effects i.e. higher resilience achieved with a capital increase versus lower resilience arising from more risk-taking - the study estimates the impact of the policy change on probabilities of default extrapolated from credit ratings. Results indicate that the positive effect of accumulating more equity capital is counterbalanced by the negative substitution effect toward more riskier assets. The overall net effect on solvency as measured by probabilities of default is thus null. At the 
same time, results indicate that rating agencies evaluate the capital increase as the prevailing effect on the probability of default of medium and large banks relative to the smaller banks.

In terms of heterogenous effects of capital requirements, the study documents that banks adopting the internal rating based (IRB) approach show a lower propensity to risk taking on their financial accounts, this evidence suggests the existence of a competitive advantage for IRB banks since lower risk weights imply a lower cost of compliance to higher capital requirements. In addition, results indicate most of the increase in risk taking is due to less profitable institutions as measured by net interest income, suggesting that they try to achieve higher returns by substituting toward more riskier assets to compensate for the low profitability. The study documents further that wholesale funded banks have a lower tendency to increase their risk profile. This result can be interpreted as a strategic need to reduce the risk taking observed by the markets to compensate for the riskier funding model inherent in wholesale funded banks. It may also be a consequence of competitive advantage arising from the capacity to exploit cross-border funding in regions where monetary policy conditions are more expansionary, see Bruno and Shin (2015).

The paper is organised as follows: Section 2 reviews the theoretical and empirical literature, the EU macroprudential regulation is presented in Section 3 while the empirical methodology is illustrated in Section 4. Section 5 presents the evidence while the robustness is presented in Section 7, the impact on the probabilities of default is described in Section 8, conclusions are drawn in Section 9.

\section{Literature}

\subsection{Related Theoretical Literature}

The theoretical literature approached the question of the relationship between higher capital and risk taking from different angles. Since the pioneering contribution of Modigliani and Miller (1958), where agents are perfectly informed and banks would always choose socially optimal risk levels, it expanded and relied on a variety of modelling techniques. ${ }^{10}$. Despite the richness of existing contributions a consensus has not been reached. According to theoretical literature, the effect of capital requirements on risk taking behavior is ambiguous and hence the relationship is still an open empirical question.

Limited liability and deposit insurance models for instance, claim that depositors do not

\footnotetext{
${ }^{10}$ Contributions range from portfolio models maximizing a mean-variance utility function (Kahane et al., 1977; Koehn and Santomero, 1980; Kim and Santomero, 1988; Rochet, 1992), models using option pricing methods to value the deposit insurance subsidy (Merton, 1977; Galai and Masulis, 1976; Furlong and Keeley, 1989), dynamic models of charter value and competition (Keeley, 1990; Blum, 1999; Hellmann et al., 2000), or the principal-agent framework, (Saunders et al., 1990; Dewatripont et al., 1994)
} 
have any incentive to monitor banks' behaviour, it follows that managers would have more opportunity to increase asset riskiness and exploit moral hazard arising from the deposit insurance subsidy, Green (1984). In these models, the moral hazard problem may be further exacerbated by the presence of informational advantage for bank managers, Jensen and Meckling (1976). Similarly, Kareken and Wallace (1978) find that in a monopoly model of banking with complete contingent claims and under an FDIC-type deposit insurance scheme, the banking industry maintains a risky portfolio and capital requirements do not forestall bankruptcy. ${ }^{11}$

Portfolio choice models support both views, on one side Kahane et al. (1977), Koehn and Santomero (1980), Flannery (1989) conclude that capital requirements are inefficient in constraining the risk shifting in the bank portfolio insulating them from market discipline. Nevertheless, Furlong and Keeley (1989) show that for a value-maximizing bank and the presence of option-value of deposit insurance, the incentives to increase asset risk decline as bank capital increases. More recently, Kim and Santomero (1988) show that the the use of simple capital ratios is ineffective to bound the insolvency risk of banks, and propose theoretically corrected risk-weights as a solution to the risk taking behaviour. Similarly, Rochet (1992) argues that utility, as opposed to value, maximizing banks can reduce risk taking if capital ratios take into account their asset risk. Blum (1999) models a dynamic decision problem of a bank to conclude that capital adequacy rules may increase bank riskiness.

Merton (1977) fostered the use of option-pricing models which consider deposit insurance as an option-value, to reach the conclusion that more skin in the game, i.e. higher capital requirements, can reduce incentives for increasing portfolio riskiness. Galai and Masulis (1976) use a capital asset pricing model and an option pricing model to show how unanticipated changes in firm capital can induce investments in portfolios with higher variance. Similarly, Gennotte and Pyle (1991) show how deposit guarantees in combination with higher capital requirements lead banks to increase asset risk.

A further strand of models uses the charter value of the bank, i.e. the difference between going concern and liquidation value, to support the skin in the game argument, Marcus (1984). By the same token, Benston (1986) argues that bank shareholders have more incentives to operate conservatively when the amount of their own funds is at risk. The prospect of loosing charter value on managers' career can remind managers of the consequences of excessive risktaking. Saunders et al. (1990) show how managers may have incentives to reduce the default risk below the shareholders desired level in order to protect their own human capital. The question is if the bank-managers have the same incentives of the shareholders. Dewatripont et al. (1994) model the classic moral hazard problem with unobservable managers' effort to conclude that

\footnotetext{
${ }^{11}$ Notice that, as convincingly showed by Diamond and Dybvig (1983) deposit insurance is at the same time a fundamental policy tool to avoid bank runs, hence notwithstanding the moral hazard incentive, deposit insurance is widely used to limit bank panics and bank runs in time of distress.
} 
banks with low leverage may have an incentive to increase risk since interference from principal is lower, and viceversa. We test for this hypothesis in section 6.2. More recently, the theoretical literature using the charter value argument was augmented by including competition in the banking industry to conclude how the presence of more competitors may reduce the charter value and increase default risk through asset risk, Keeley (1990), Hellmann et al. (2000).

\subsection{Related Empirical Literature}

Previous empirical research on the impact of higher capital requirements on bank risk-taking is scant. Pioneering empirical contributions focused on the introduction of risk-weighted regulatory standards in the late 1980s and was rather fervent in the 1990s. It used descriptive regression analysis and simultaneous equation models relying thus on endogenous components of capital increase by bank managers, (Shrieves and Dahl, 1992; Jacques and Nigro, 1997).

One of the earliest empirical contributions is provided by Shrieves and Dahl (1992). The authors adopt a two-stage simultaneous equation estimation to analyze the relationship between risk and capital. They estimate discretionary changes in asset portfolio risk induced by a variation of capital taken endogenously by the bank. The authors find a positive relationship between increased capital levels and risk taking as measured by average risk-weights. The positive relation holds also for banks with capital in excess of the minimum requirements, leading the authors to conclude that risk-taking behaviour is influenced by bank owners' and/or managers' private incentives.

Haubrich and Wachtel (1993) apply an analysis of variance (ANOVA) to study whether the 1998 risk-based capital accord (Basel I) led to the risk shifting of commercial banks' portfolio toward government securities and hence a lower average risk-weight. The authors conclude that the implementation of Basel I fostered risk reduction, with poorly-capitalized banks shifting their portfolios away from high-risk assets and towards low-risk assets.

Using a three-stage least squares simultaneous equation model, Jacques and Nigro (1997) examine the impact of the risk-based capital standards on bank capital and portfolio risk in the first year the Basel risk-based standards were in effect. As in Shrieves and Dahl (1992), they use discretionary bank management adjustments to capital, and measure risk as the ratio of risk-weighted assets to total assets. The paper concludes that risk-based capital standards were effective in increasing capital ratios and reducing portfolio risk for banks which already met the new risk-based standards. Interestingly, Jacques and Nigro (1997) define also a supervisory pressure variable assuming that banks may respond differently depending on whether they are in excess or in shortage of required capital. For capital-constrained banks the responses showed little connection to the degree to which they fell short of the standards. Applying a similar simultaneous equation framework to a sample of Swiss banks, Rime (2001) finds that 
supervisory pressure induces banks to increase their capital, but does not affect the level of risk.

After the turn of the century, academic focus on the impact of bank capital requirement on risk-taking has subdued. More recently, Gropp et al. (2016) exploit the 2011 European Banking Authority (EBA) capital exercise ${ }^{12}$ and a difference-indifference matching estimator to find that treated banks increase capital ratios by reducing their credit supply. On the margin of their study, the authors show that the EBA capital exercise did not have significant effects on risk reduction as measured by the risk-weighted asset to total asset ratio. Similarly, Calomiris and Jaremski (2016) exploit a staggered implementation of deposit insurance laws in the U.S. and the fact that those laws were applied only to some depository institutions within the states to corroborate the theoretical literature on the moral-hazard consequences of deposit insurance.

\section{The EU macroprudential capital based regulation}

One of the criticisms of earlier Basel standards for capital requirements, is the lack of emphasis on risks stemming from correlated exposures that may accumulate over time and increase systemic risk, (Hellwig, 1995; Acharya, 2009; Haldane and May, 2011). Basel I and II capital standards are focused exclusively on individual portfolios without acknowledging the importance of how much these portfolios are diversified, the pattern of co-variances among individual assets, systemic correlation of risks and interconnectedness, and/or the cost of failure of big and more complex banks. ${ }^{13}$

Basel III standards include additional capital requirements aimed at tackling some of these issues and add three main new buffers: the Capital Conservation Buffer (CCoB) for build-up of adequate buffers above the minimum that can be drawn down in periods of stress, the Countercyclical Capital Buffer ( $\mathrm{CCyB}$ ) aimed at limiting the procyclicality of credit growth, and additional capital buffers for Global Systemically Important Banks (G-SIB) aimed at addressing the liquidation cost of too-big-to fail banks. ${ }^{14}$ These efforts notwithstanding, critics have questioned both the lack of ambition and the design of some of the Basel III buffers Repullo and Saurina (2011).

\footnotetext{
${ }^{12}$ The EBA capital exercise required 61 banks to build-up additional capital buffers to reach a level of $9 \%$ core tier 1 ratio in 8 months, from 26 October 2011 until June 2012

${ }^{13} \mathrm{On}$ one hand Basel I introduced risk-weighted exposures in order to force banks with more risk in their portfolios to maintain a higher capital level, while Basel II main innovation was the introduction of the Internal Rating Based (IRB) and the Standardized Approach (SA) models for the computation of risk-weights. For a more detailed history of Basel capital standards and their deficiencies see for instance Brealey (2006) and Hellwig et al. (2010).

${ }^{14}$ In addition, Basel III introduces favourable risk-weights for OTC derivatives cleared through central counterparties (CCPs), and is raising the risk-weights on exposures to financial institutions relative to the non-financial corporate sector, as financial exposures are more highly correlated than non-financial ones.
} 
In Europe, the Capital Requirements Regulation (CRR) and the Capital Requirements Directive (CRD IV) introduced a new macroprudential framework transposing the Basel III agreement. ${ }^{15}$ The CRDIV has been officially transposed in law on 17th July 2013 and the full reform package entered into force on the 1st January 2014. The overarching goal of the new EU regulation is to limit systemic risk in the banking sector through the introduction of a set of Systemic macroprudential Capital Requirements (SMCR) available to national authorities to address systemic risks. The set of SMCR include three main capital based instruments: the Systemic Risk Buffer (SRB), the Other Systemically Important Banks (O-SIB) buffer and the Globally Systemically Important banks (G-SIB) buffer. ${ }^{16}$ The SRB aims to address systemic risks of a long-term structural and non-cyclical nature as for instance the accumulation of systemic risk and the degree of interconnectedness. The O-SIB and G-SIB buffers are predominantly concerned with increasing loss absorption capacity and reducing public costs of default of bigger and complex banks.

While the economic rationale behind the diverse types of buffers may differ in scope and objective, all of them have to be met with an additional highest quality Common Equity Tier1 (CET1) capital as a share of risk-weighted assets (RWA). All SMCR are applied at individual bank-level and levied in addition to the minimum requirements, and they are specifically addressed to a set of both globally and nationally systemically important banks (SIBs). ${ }^{17}$ The list of systemically important banks is updated each year by national authorities following EBA guidelines. The main criteria for systemic importance are: a) size; b) importance for the economy of the relevant Member State or the Union, capturing substitutability/financial institution infrastructure; c) complexity, including the additional complexities from cross-border activity; d) interconnectedness of the institution or (sub-)group with the financial system. ${ }^{18}$

It is important to notice that not all G-SIBs or O-SIBs are subject to the SMCR as of 2017Q3. In fact, despite the introduction of the capital based macroprudential framework in

\footnotetext{
${ }^{15}$ Detailed information on the Capital Requirements Regulation and Directive can be found on the European Commission website. Norway and Iceland, despite not being formally EU Member States opted for participating in the new EU macroprudential framework for banks as established in the CRR and the CRDIV.

${ }^{16}$ The new macroprudential regulation in the EU includes also the Basel III capital conservation buffer (CCoB) as well as the dynamic countercyclical capital buffer $(\mathrm{CCyB})$. Nevertheless, the CCoB and the CCyB are buffers set at the country-level and hence at the same level for systemic and non-systemic banks in the country. Since these two buffers are absorbed by country-quarter fixed effects in our empirical design they are not contributing to additional variation and to the identification of the effects.

${ }^{17}$ Under the CRD IV/CRR capital framework, EU banks are required to hold a minimum amount of total capital equal to at least $8 \%$ of risk-weighted assets (RWA). The new regulation raises the minimum share of capital that has to be of the highest quality common equity tier 1 (CET1) from $2 \%$ to $4.5 \%$. Additional capital until the minimum threshold of $8 \%$ can be fulfilled with Tier 1 minimum capital or Tier 2 minimum capital (max. 2\%). As such, the new EU-wide CRD IV/CRR minimum capital regulation places greater emphasis on the quality of capital.

${ }^{18}$ For more details cfr. the EBA Guidelines on the criteria to assess systemically important banks in the EU. The EBA provides and maintains also an updated G-SIBs list and O-SIBs list in Europe over time on its website.
} 
2014 in the EU, some national macroprudential authorities have not yet activated any of the structural SMCRs. Under the oversight of the ESRB and the ECB, the EU regulation allows for discretion to activate and to set the level for each O-SIB and SRB buffer. On the one hand, these country divergences and the staggered implementation across countries facilitate the empirical identification problem. On the other hand, they may lead to concerns regarding the potential endogeneity of the policy change with respect to the health of the country banking system. These concerns are, however, alleviated by four main elements enshrined in the regulation: i) four EU institutions coordinated oversight contribute to refraining from inaction bias and national favoritism, ${ }^{19}$ ii) the ECB has the power to top-up the requirement if considers it insufficient to cope with the relevant risk, or may object the decision in case considered excessive or punitive toward foreign subsidiaries, and iii) the ESRB can issue public warning and recommendations where an identified systemic risk has materialised and has not yet been addressed and iv) the reciprocation framework allows a Member State to request a reciprocation of a macroprudential measure. ${ }^{20}$.

The calibration of the G-SIB buffer is set internationally according to the Basel G-SIB score range for each G-SIB, BCBS (2013). The calibration of the SRB and the O-SIB buffers depend on the systemic importance of the bank for the country in question and is not subject to centralized guidelines from EBA. As mentioned earlier, the ECB has developed a framework to provide a minimum common floor when calibrating O-SIB buffers at the national level to foster a level playing field. Above this floor, each country calibrates the buffers using own methodologies. $^{21}$

In sum, and contrary to the Basel III capital standards, the EU package is more ambitious since instructs Member States to designate own systemically important banks to which then a wider battery of bank-specific systemic capital buffers may be applied. Figure 1 provides an overview of the newly introduced capital requirements in the EU.

\footnotetext{
${ }^{19}$ It is important to notice that in order to ensure consistent macroprudential oversight across the Union, the European Systemic Risk Board (ESRB) develops principles tailored to the Union economy and is responsible for monitoring their application.

${ }^{20}$ See respectively, Article 131(7) of the Capital requirements Directive IV (CRDIV), Articles 5(1) and 5(2) of the Single Supervisory Mechanism Regulation, Article 3 of the ESRB regulation and the Recommendation of the ESRB/2015/2 in conjunction with Article 5 of Decision ESRB/2015/4

${ }^{21}$ For instance, the Commission de Surveillance du Secteur Financier (CSSF), the macroprudential authority in Luxembourg adopts "a statistical approach involving linear regression and a scaling framework with the goal to ensure consistency between O-SIBs buffers and the buffers applied to G-SIBs." See CSSF notification to the European Systemic Risk Board (ESRB). Additional notifications may be found on the ESRB website.
} 


\section{Empirical Methodology}

\subsection{Data}

This study uses two main data sources to construct an integrated dataset combining banklevel financial accounts data and systemic macroprudential capital requirements. The source of bank-level financial accounts data is the commercial provider SNL Financials which collects financial accounts from financial institutions around the World. More specifically, financial accounts for all G-SIB and O-SIB in the EU and Norway from 2006Q1 until 2017Q3, leading to a total number of 205 banks in the sample, with 14 G-SIBs and 191 O-SIBs. ${ }^{22}$ The list of banks sorted by total assets is presented in Appendix $9^{23}$.

The bank specific systemic macroprudential capital requirements are obtained from the ESRB database on macroprudential policies based on the notifications from the national authorities. $^{24}$ Table 3 illustrates the evolution of capital requirements for the sample of EU G-SIBs and O-SIBs from 2010Q1 until 2017Q3. In Panel A of Table 3 the simple mean of the capital requirements for both treated and non-treated banks is shown. The first row shows the phasing-in of the SMCR after 2014. From 2014 onward the SMCR CET1 capital requirements for EU G-SIBs and O-SIBs increase by an average of 0.21 percentage points yearly. ${ }^{25}$

The average capital requirement is higher if we compute the average conditional on treated banks. As explained in Section 3, an O-SIB may not have any systemic macroprudential capital requirement if the regulator decides not to implement any, see Figure 1 for a summary of the macroprudential capital requirements in the EU. In our sample $26.34 \%$ of bank-quarter

\footnotetext{
${ }^{22}$ For the list of G-SIB with cut-off date 2016Q4 consult the Financial Stability Board page available on this link.

${ }^{23}$ One caveat to keep in mind when constructing a bank-level database over a long time period is the churning rate of financial institutions from the sample. In particular the merger of two or more financial institutions may bias the results. To limit this possibility, When a merger happens, the study sample is adjusted in order to reflect this change: old entities are discontinued in the sample and a new entity is added with a separate identifier as a result of the merger. To grasp the idea of sample construction in case of mergers, one examples of recent merger episodes over the period is shortly summarised in this footnote. On 2nd Jan 2017 Nordea Bank Denmark merged with Nordea Bank AB, see link. As a consequence of the merger, a Danish entity Nordea Real Kredit has been identified as O-SIB by the Danish macroprudential authority. It follows also that Nordea Bank Denmark has been removed from the O-SIB list in DK, and also from the list of O-SIBs in the study sample.

${ }^{24}$ The ESRB macroprudential database covers all changes in macroprudential regulation notified by the 28 EU countries and Norway. Notifications are published on the ESRB website or disseminated through ESRB publications. For detailed information on the national macroprudential policies in the EU cfr.: ESRB National Policies

${ }^{25}$ Note that over the sample period, other type of country level macroprudential buffers were also levied on EU banks, as for instance the $\mathrm{CCoB}$ and the $\mathrm{CCyB}$. The total combined yearly average of macroprudential buffer averaged $0.65 \%$ from 2014 until 2017Q3. However, in this paper, the focus is exclusively on bank-level macroprudential buffers since they allow for more precise estimates and allow to control for time varying countrylevel variation by including country-time fixed effects. In other terms, the country-time fixed effects absorb the variation generated by the country-level capital requirements. Note also that there is a small average increase (i.e. $0.01 \%$ ) of the SMCR across the sample already in 2013 since in Norway the macroprudential capital requirements where the Systemic Risk Buffer (SRB) was introduced in 2013Q3.
} 
observations are not treated. This conditional mean is shown in Panel B of Table 3 and implies an average increase of the SMCR by 1.18 percentage points in 2017Q3. This is a substantial increase in capital requirement, in particular for banks that are closer to the minimum requirement. An inspection of the standard deviation of SMCR shows the ample variation in capital requirement setting. This is a welcome feature of the data since it contributes to lower the variance of the estimated coefficient of interest and provide more precise estimation of the relationship between risk-taking and capital requirements.

The second row of each panel of Table 3 shows the overall capital requirement for CET1 capital (OCR), i.e. the sum of the Pillar I capital requirements and the Combined macroprudential Capital Requirement. The average banks' supply levels of CET1 capital are shown in the third row of each panel. The difference between the OCR and the supply of capital by banks is then computed in order to derive a proxy for the stringency of the capital requirement at bank-level (row four). In fact, banks' response to higher capital requirement are expected to be a function of the distance to the regulatory minimum, or in other words an inverse function of their excess capital above the minimum requirement. Banks are expected to increase their capital supply if they are close to the regulatory minimum as shown already by Jacques and Nigro (1997) and Rime (2001).

Table 4 illustrates descriptive statistics of banks' financial accounts as extracted from the SNL Financials database. Descriptive statistics are shown for all variables used in the later empirical analysis, when absolute values are shown these are expressed in USD throughout the paper. The asset side of the balance sheet is composed by three major components: loans gross of provisions for impairment $(58.29 \%)$, securities $(25.13 \%)$ and cash $(15.29 \%) .{ }^{26}$ It is worth noting the average level of RWA over total assets, i.e. the risk-ratio, which is $50.91 \%$, as this measure will be a useful benchmark for the following analysis. Securities can be further broken down by Held for Trading (HFT), Available for Sale (AFS) and Held to Maturity (HTM). On the liabilities side the table shows the means of the main funding sources for banks: deposits (48.5\% of total assets), short and long-term wholesale funding (33.3\%) and debt (17.9\%). ${ }^{27}$

Importantly, the SNL Financials database also allows to capture the extent to which systemically important financial institutions are interconnected with each other and the wider financial system. In fact, excluding measures of bank interconnectedness and complexity would bias the results due to their direct correlation with the level of the SMCR, see Section 3 above and EBA Guidelines on the criteria to assess systemically important banks in the EU. Table

\footnotetext{
${ }^{26}$ Cash includes reserves and balances at the Central Bank, operating cash, cash and cash equivalents according to the relevant accounting standard, i.e. "short-term, highly liquid investments that are readily convertible to known amounts of cash and which are subject to an insignificant risk of changes in value".

${ }^{27}$ The total sum of funding sources and equity is not $100 \%$ of total assets due to missing observation across these variables.
} 
4 presents four indicators used in the paper as proxies for interconnectedness and complexity, namely: i) interbank lending as a direct measure of interconnectedness; ii) assets held for trade as measure of complexity and interconnection with financial markets' developments through mark-to-market trading book accounting which directly impacts banks' profit and loss statements; iii) over the counter (OTC) derivatives securities held on the balance sheet as a measure of both complexity and interrelation with the counterparty risk in he financial system; iv) cash held at the Central Bank for interbank payments' settlements. ${ }^{28}$

\subsection{Empirical Design}

The introduction of the CRD IV/CRR regulatory framework and of the new macroprudential capital requirement offers an opportunity to employ an identification strategy based on a controlled comparison by studying the effect of a policy change on differently affected banks. As noted in previous sections, the SMCRs are set at individual bank-level for systemically important banks in the EU and banks within a country may well have different level of requirements depending on their systemic importance. This ensures cross-country and within-country variation, which is suited for using a multi-treatment group difference-in-difference identification strategy. In other words, similar banks that are affected differently by the capital requirement are compared across time. ${ }^{29}$ For the identification strategy to be valid, the underlying assumption is the common trend behaviour in the outcome variable before the policy implementation. Two verification tests for this hypothesis are presented in Section 7. The first includes bank trends in the specification to test the robustness of the findings to the influence of confounding pre-existing trends following Wolfers (2006), the second test looks at the anticipation and announcement effects. The baseline estimated equation is:

$$
\ln Y_{i c t}=\alpha_{i}+\beta \Delta S M C R_{i c t}+\ln X_{i c, t-1} \gamma+\delta_{c t}++u_{i c t}
$$

Where $i, c$ and $t$ are indicators for bank, country and time respectively. The specification includes bank fixed effects, $\alpha_{i}$, to control for time-invariant bank heterogeneity. Importantly, the parameters $\delta_{c t}$ are dummy variables for capturing within state endogenous variation, for instance time varying macroeconomic effects such as: general economic growth, supply and demand shocks or fiscal and monetary policy changes within a country. The country-quarter

\footnotetext{
${ }^{28}$ Cash held at the central bank is also an important bank-level control variable for unconventional monetary policy operations of quantitative easing whereby bank's accounts at the ECB were credited with cash after monetary policy operations.

${ }^{29}$ In this setting each bank is a group of treatment and is compared with other treated banks in terms of intensity of treatment (i.e. different levels of capital requirement increases) and with the group of banks that had not have any increase in the SMCR over the sample period. For details on the multi-treatment group difference-in-difference estimation technique see Chapter 5.2. in Angrist and Pischke (2008).
} 
fixed effects control thus for a series of time varying country level effects and help to isolate the impact of an increment of capital requirements on the outcome of interest. Finally, $u_{i c t}$ is the residual unexplained term.

The outcome variables of interest are grouped in the vector $Y_{i c t}$, they are: the capital ratio (CET1/RWA), the level of CET1 and the level of total capital for capital specifications; RWA, and its decomposition in RWA/Assets and total assets for risk specifications. The policy variable of interest is the change in the systemic macroprudential capital requirement $\triangle S M C R_{i c t}$. Both the outcome and the policy variables are used at time $t$. The main coefficient of interest in the equation is $\beta$, which can be interpreted as the average treatment effect of a one percentage point increase in capital requirement on the outcome variable of interest.

The matrix $X_{i c t-1}$ includes bank-specific, time varying control variables lagged by one quarter to limit simultaneity bias. ${ }^{30}$ The set of control variables is motivated by the nature of the setting and calibration of capital requirements as per the EBA guidelines, which both depend on the size of the bank (total assets), the value of domestic payments (central bank reserves used for settlement of payments), the importance of the bank in the financial system (deposits and loans). As mentioned in section 4.1, the capital requirements are a function of the complexity and the interconnectedness of a bank with the financial system, hence the model controls for interbank lending, held for trading securities, OTC derivatives and cash at the Central Bank. Finally, in order to improve the precision of the estimates the specification controls for total debt, other accounting classifications of securities holding (i.e. available for sale and held to maturity), return on assets and the cost to income ratio as further controls.

\subsubsection{Bank Risk Measure}

In terms of measurement, one of the most important elements of the analysis presented in this paper is the measurement of risk-taking behaviour which must be able to identify individual bank specific risk-taking behaviour. One way to approach this problem is to look directly at the intrinsic risk stemming from the combination and composition of the portfolios on the assets side of banks' balance sheet. This is the approach followed by the Basel Committee on Banking Supervision (BCBS) under the Basel II rules on risk sensitive capital requirements.

But how can banks adjust their CET1 ratio after an increase in the regulatory capital

\footnotetext{
${ }^{30}$ More specifically, the full set of control variables includes the lags of: the natural logarithm of total assets and the natural logarithm of net loans (i.e. net of provisions for impaired loans); and a series of variables all divided by total assets: total deposits, total debt, total cash and like cash instruments, securities held for trading (HFT), securities classified as available for sale (AFS) and securities held to maturity (HTM), OTC derivatives securities, interbank loans, total balances at the $\mathrm{CB}$, return on assets ratio, the cost to income ratio.
} 
requirement? A look at the CET1 ratio can help discerning the effects:

$$
C E T 1 \text { Ratio }=\frac{C E T 1}{R W_{a} A s s e t_{a}}
$$

where CET1 is the amount of Common Equity Tier 1 capital held by the bank, RW represents the non-negative risk weight specific to asset $a$, and Asset is the amount of nominal exposure in asset $a$. As Equation 2 shows, banks can increase their regulatory capital ratio in three mutually non-exclusive ways: by increasing capital, reducing the risk-weights or reducing their assets. A bank can raise capital by either issuing new shares and/or not paying dividends to its shareholders to retain earnings. The newly issued shares and retained earnings increase the CET1 ratio, provided that the bank does not increase its risk-weighted assets. Alternatively, holding equity constant, the management of the bank can reduce risk-weighted assets, either through shifting assets composition towards exposures with lower risk-weights such as government securities, or reducing assets, that is by reducing lending, selling securities, impaired loans or other assets.

From Equation 2 a logical approach for the measurement of bank specific risk taking behaviour lies in the Basel II rules on risk-sensitiveness of assets. The ratio of RWA over total assets, for simplicity the risk ratio or risk density, is a natural measure of bank risk taking behaviour if we keep fixed the risk weights measurement approach. The risk ratio provides the average risk the bank's portfolio according to the risk-weight associated with each asset. It has the advantage of being a simple and very intuitive measure of bank risk taking, Berger (1995), even if the appropriateness of risk-weights has been questioned in the literature, see Hellwig et al. (2010). A further benefit of using the risk ratio is that it takes into account the deterioration of the quality of a credit portfolio, as already noted by Shrieves and Dahl (1992); Jacques and Nigro (1997). In fact, regulatory provisions foresee higher risk-weights for non performing exposures and impaired assets. ${ }^{31}$

In addition, the risk ratio indicator is a decision variable within the reaction function of banks' risk-management and its decision making process to changes in capital requirements determined by the regulator. The response of the risk management is exclusively determined by strategic decision and thus more apt to measure risk-taking behaviour than market based risk measures such as CDS spreads which are usually measures of solvency. In addition, the latter are of minor interest since they are external to the decision making of the banks management, and are a mere reflection on how the financial markets judge the probability of the bank being

\footnotetext{
${ }^{31}$ Some authors suggest to use directly non-performing loans (NPLs) as proxies for risk-taking since granting high-return, but high-risk, loans underlines a risk-taking propensity. However, NPLs would not be entirely apt to our task due to lags in their accounting rules, they are recognized as non-performing starting on the 90th day past due (depending on the type of asset and the accounting classification) implying a difficult identification problem for the econometrician regarding the timing of the impact.
} 
solvent when payments are due. ${ }^{32}$

A further advantage of the use of internal risk-weights is that they provide for a not delayed response when an increase in capital requirements occurs. this is primarily driven by supervisory interference and sanctions due to late compliance.

Some notes of caution in using the risk ratio are due. Banks using internal rating based approach (IRB) to set risk-weights on their portfolio have a competitive advantage with respect to banks using standardized approach (SA). The competitive advantage arises because IRB banks use their own empirical models to estimate efficiently market and credit risk, while SA banks use the risk weights defined in the regulation which are on average more stringent. Internal rating models are fine-tuned to minimize the risk weights for each risk exposure. This study controls for this heterogeneity using bank-level fixed effects, in addition it explores the extent of the competitive advantage of IRB banks by interacting the macroprudential capital requirement with an IRB dummy in Section 5.

A final note of caution is due since, by construction, the risk ratio identifies risk stemming predominantly from on-balance sheet exposures, while the risk associated with unobserved offbalance sheet exposures is not entirely captured in this metric. In the transposition of Basel standards in the EU, the CRR asserts that off-balance sheet items are treated like on-balance sheet exposures and shall be risk-weighted, however the calculation method implies a lower risk weight for off-balance sheet exposures. ${ }^{33}$ Since off-balance sheet items are unobserved in the dataset, we can only try to form an educated guess on the bias arising from omitted variable. Table 2 shows the direction of omitted variable bias given the correlation patterns between the omitted variable, the treatment variable and the dependent variable. Due to the preferential regulatory treatment for off-balance sheet assets, it is very likely that banks react to higher capital requirement by shifting some of their risky assets to unobserved off-balance sheet positions implying a positive correlation between regulatory capital hike and off-balance sheet activity. In addition, due to lower risk weights of off-balance sheet exposures, the $\beta_{2}$ coefficient in Table 2 should be lower than zero. It follows that the estimates on the impact of capital requirements on risk taking behaviour may result downward biased if the incidence stemming from off-balance sheet items is large enough. This downward bias may underestimate the real risk-taking behaviour in our estimates, probably even more for more complex institutions which

\footnotetext{
${ }^{32}$ It is also important to notice that the scope of application of CDS pricing is very limited in our sample since CDS prices are generally available only for some of the large systemic banks. In our sample, this translates to only 49 banks with available CDS prices.

${ }^{33}$ Not all activities of the banks can be moved off-balance sheet, off-balance sheet items are typically exclusively those not owned by or not a direct obligation of the bank, for instance securitised activities and operating leases are the most common off-balance items. The key difference between off-balance and on-balance exposures relates to the calculation method of the exposure value that should be risk-weighted. The definition and calculation of the exposure value of off-balance sheet items is detailed in CRR Article 166 for the IRB approach and CRR Article 111 for the SA.
} 
have a higher capacity to transfer assets off-balance sheet.

\section{Results}

By presenting the first set of results, the paper acknowledges that banks tend to maintain a capital buffer on top of the regulatory minima as a signal of financial health to the markets, to attract funding and to minimize supervisory interference Shrieves and Dahl (1992); Jacques and Nigro (1997). Moreover, microprudential supervisors encourage banks to maintain an additional voluntary buffer on top of the minima, this indicates the adequate level of capital to be maintained in order to withstand stressed situations. ${ }^{34}$ This study sorts banks by how binding is the new capital requirement. To this end, an indicator of the distance from the OCR is interacted with the change in the systemic macroprudential capital requirement. ${ }^{35}$

\subsection{Capital: Baseline and binding distance interaction}

Before investigating the relative importance of the moral hazard versus the skin in the game channels, it is instructive to understand how effective the capital requirement is at increasing the banks' capital. This section provides evidence on whether banks increase the numerator of the capital ratio and, as a consequence, whether their solvency is strengthened. Table 5 illustrates the results of the impact of an increase in the Systemic macroprudential Capital Requirements (SMCR) on three measures of capital: the risk-weighted CET1 ratio, the volume of available CET1 capital and the volume of supplied total capital. All regressions follow the specification in Equation 1, and include quarterly varying country-time fixed effects. The first columns (1)-(3) present the baseline estimates, while Columns (4)-(6) differentiate the impact by the cushion banks maintain from the OCR.

Column (1) shows how the resulting average impact on the risk-weighted capital ratio is not statistically significant. For the average bank, and without categorizing banks by distance from the minimum requirement, the impact of the SMCR is not strictly binding. This result is however not distinguishing by the buffer banks maintain on top of regulatory minima. ${ }^{36}$

\footnotetext{
${ }^{34}$ In the Banking Union framework, this is regulated via an additional Pillar 2 Guidance which is calibrated on the basis of the adverse scenario in the supervisory stress tests. see ECB description of the Pillar 2 Guidance

${ }^{35}$ In turn, levels of desired capital may depend on external factors such as the macroeconomic environment, the market interest rate, the degree of tax differentials between debt and equity financing Schepens (2016), as well as the degree of regulatory pressure. In a bank-level empirical setting, the country-level features can be controlled for in specification 1 via country-time fixed-effects, these help to absorb the bias in the estimates arising from country-level specific influences.

${ }^{36}$ In the following note that the estimation sample is composed by 137 significant banks, the distribution of the OCR distance variable in the estimation sample has mean 8.7 percentage points and median at 7.8 percentage points. Similar results are obtained with different break-down of the distance from OCR, the results are available from the author.
} 
Column (4) indicates that once we include in the regressions dummies for distance, and their interaction with the SMCR, a one percentage point increase in the capital requirement induces an increase of the CET1 ratio by 0.83 percentage points, providing evidence that significant European banks are effectively constrained by the regulatory change. The interaction effect is not statistically different for the group of banks with a more than two percentage points excess capital with respect to the minimum requirement. The absence of negative sign for non capital constrained banks, provides evidence that the reaction to the hike in capital requirement is widespread. This finding is in line with the notion that banks have a preference to maintain a desired, or target level of capital, above the minimum to assuage market pressure and reduce supervisory interference, Shrieves and Dahl (1992); Jacques and Nigro (1997)

But how this increase in the ratio occurs? In Column (2), the focus shifts to the amount of CET1 capital, i.e. the numerator of the CET1 ratio. On average, a one percentage point higher SMCR yields CET1 to increase by 8.9 percent. In Column (5), we differentiate the impact by distance to OCR: the result highlights again that banks with a relative shortage of capital have almost a double effect (17.7 percent) with respect to the average impact in column (2). The coefficient for the reference group of banks with less than 2 p.p. of CET1 buffer above the minimum, translates in a 17.7 percent increase of CET1 ratio for a 1 p.p. rise in capital requirements. This positive impact on the numerator of capital constrained banks provides evidence of the direct benefits of capital-based macroprudential regulation in the EU. The reforms promoted widespread increase in capital levels across the sample of systemically important banks, and in particular for banks with lower loss absorption capacity, increasing therefore the overall resilience of the system. Yet, significant banks with capital in excess of the minimum regulatory threshold show some weaker effects, both in terms of the magnitude of CET1 capital increase and the significance level of the impact. This result for non capital constrained banks, coupled with the result in Column (4), indicates that the weaker negative effect is compensated by the reactions in the denominator of the CET1 ratio.

Column (3) and Column (6) corroborate the results on CET1 capital when including additional Tier1 capital and Tier2 instruments in the numerator. The net impact is attenuated since the bulk of the increase is borne by CET1 capital, a natural consequence of the SMCR requirement. The induced higher levels of capital ratios mean a greater loss absorption capacity for European banks when the next financial crisis hits, Jiménez et al. (2016).

\subsection{Risk: Baseline and binding distance interaction}

This section presents the first results on the skin in the game versus moral hazard channels. It shows how the banks react to their strengthened capital position which was documented in the previous section. 
As summarized in Section 2, a branch of the banking literature shows how more regulated banks can have risk-taking incentives due to the negative effect of higher capital requirements on bank profits. ${ }^{37}$ On the other hand, the skin in the game argument postulates that for banks with higher capital ratios there is an incentive by bank managers to avoid excessive risk-taking since more risk increases the variance of returns with higher probability of significant losses on banks' equity. ${ }^{38}$. This section shed lights on the capital requirements and risk-incentive relationship using the risk ratio as a measure for riskier assets, and interacting the SMCR with the distance from the OCR in order to study the interaction of risk-taking with the supply of regulatory capital.

Table 6 presents the estimates. Columns (1)-(3) investigate the effect without distinguishing banks by their distance from the overall capital requirement. Column (1) shows the estimates on the impact on the combined risk weighted assets, columns (2) and (3) presents the impact on the decomposition of RWA in risk ratio (or density) and total assets. The results suggest that, on average, banks show a significant tendency to increase their RWA after a tightening of the capital requirements. In particular, as shown in Column (2), the impact stems from higher risk taking, as the composition of the asset side of banks' balance sheets tilts toward more riskier assets. The risk taking behaviour manifests in considerably higher risk ratios (RWA/Assets), with a one percentage point hike in capital requirements being associated with 6.9 percentage points increase of the risk ratio. The estimates are significant at 1 percent confidence level and are indicative of the existence of a risk taking channel of capital adequacy requirements, raising concerns on the non-intended consequences and perverse effects of capital based regulation.

To understand better the magnitude of this impact, recall that the average risk ratio level in the sample is 50.9 percent (see Table 4). In other words, a one percentage point increase in the SMCR could shift the average risk ratio to 57.8 percent. This is an economically significant amount and, as noted in section 2, the qualitative impact is consistent with previous theoretical and empirical work. Moreover, we can try to extrapolate this impact to the average EU systemically important bank, we can compare how much this risk taking relates to the effective increase in capital requirement occurred during the observation period. Table 3 shows that over the four years between 2014 and 2017, the SMCR increase on average in the sample of systemically important EU banks by 0.87 percentage points. A simple linear approximation would thus entail an average increase of risk weights by 6 percentage points, i.e. 0.87 multiplied by 6.9 the coefficient of Column (2).

The second part of Table 6 tests the hypothesis of a non-linear relationship between capital requirement and risk taking, Hellmann et al. (2000); Repullo and Suarez (2004); Repullo (2004).

\footnotetext{
${ }^{37}$ See for instance Koehn and Santomero (1980); Kim and Santomero (1988); Blum (1999).

${ }^{38}$ See for instance Hellmann et al. (2000); Repullo and Suarez (2004); Repullo (2004)
} 
Contrary to the predictions of this strand of the literature, the evidence in Columns (4)-(6) does not show signs of a decreasing risk taking behaviour by banks with a greater supply of capital. In fact, all the interaction terms in the specification are not significant at standard confidence levels. All groups of banks, irrespective of their level of capital supply, show similar propensities to take on more risk after a hike in capital requirements.

The results of this section show a clear tendency to react to more capital by shifting the portfolio toward riskier assets. The predisposition to take on more risk can be interpreted as evidence that the moral hazard channel is stronger than the skin in the game channel of capital regulation. Potential losses to equity holders arising from greater risk taking are not the main driver of risk management decisions in the adjustment process. The positive aspect of the new regulation is that banks react by increasing the amount for capital even if this does not restrain them from taking on more risk.

\section{Heterogeneity}

\subsection{Heterogeneity by Size and IRB}

This section investigates how size and internal rating based approach affect the relationship between capital requirements and risk taking behaviour. Bank size is measured using total assets, with small banks classified as those having less than USD 20 billions in total assets, medium banks defined as banks with assets between USD 20 to USD 100 billions and large banks have more than USD 100 billions in total assets. ${ }^{39}$

Further, banks are distinguished by their risk weights measurement approach in order to gauge whether more sophisticated financial institutions can successfully circumvent the riskweighting system and present lower risk-weights on their books. The indicator variable for the IRB approach is constructed from SNL Financials where the risk weights measurement framework is provided and the dummy takes value one if the bank is using either the advanced or the foundation IRB. ${ }^{40}$ A priori, we expect a positive correlation between size and IRB, due

\footnotetext{
${ }^{39}$ The classification of banks follows a division of the sample in three approximately equal parts in order not to lose observations and hence statistical power when performing heterogenity effects, see Table A-I. For the smaller banks, this subdivision is also in line with the EU Banking Union criteria to distinguish Least Significant Institutions (i.e. total assets < USD 30 billions) and Significant Institutions (total assets > USD 30 billions). Other thresholds for size have been tested and results do not alter the conclusions presented in this section. Regressions by other categorizations are available from the author.

${ }^{40}$ There are two versions of the IRB approaches. The Advanced (A-IRB) is the most sophisticated of two credit risk modelling approaches agreed by regulators in 2004. It allows banks to calculate the probability of default (PD) for a loan, as well as the exposure at the point of default and the resulting losses. Its simpler cousin, the foundation IRB, only allows PD to be modelled. In the following we consider a dummy one for banks using either the A-IRB or the foundation IRB approaches, or a mixture of the two. The dummy is set to zero for purely standardized approaches (SA).
} 
to resource constraints smaller banks may not have the required human capital to design and deploy the IRB approach which is more demanding in terms of modelling skills. In our sample, size and IRB have a positive pairwise Paerson correlation coefficient of 0.31 , this correlation is significant at one percent significance level. Table 7 presents the evidence on the impact of a hike in capital requirements for capital indicators, while Table 8 shows the estimates for measures of risk. All regressions include bank-level controls, bank fixed effects and country-quarter fixed effects, the latter control for time varying macroeconomic heterogeneity.

\subsubsection{Impact on Capital by Size and IRB}

Following the results in Section 5.1, Table 7 adopts the specification with a dummy variable for distance which is 1 if the distance from the OCR is greater than two percentage points, for the sake of space and according to the results of Table 5 the dummy for distance takes on only two values. ${ }^{41}$ The estimates on the impact of capital do not present strong evidence of hetereogeneous impact by size or risk weights measurement framework. The interaction with the distance from the overall capital requirement is likewise not significant. The evidence on capital raising from Table 7 leads to conclude that there is no significant heterogeneous behaviour between small and big banks or between banks adopting the IRB or the SA.

\subsubsection{Impact on Risk by Size and IRB}

The results related to the risk taking behaviour are more informative. Table 8 illustrates the outcome of the regression, this time without differentiating by distance from the OCR since risk taking behaviour does not appear to be related to the buffer of capital the bank maintains on top of the minimum requirement, this was shown in Table 6. Columns (1)-(3) show the results by bank size while Columns (4)-(6) present evidence for banks with IRB and for the interaction of size and IRB.

Column (1) of Table 8 indicates that RWA are increasing by approximately seven percent for a one percentage point increase of capital requirements. The impact on RWA does not appear significantly different between smaller and bigger banks. In Column (2), RWA are divided by total assets to obtain the risk ratio. ${ }^{42}$ The evidence indicates a clear increase of the impact on the risk ratio as the size of the banks increases. Banks with total assets above USD 20 billions tend to take on more risk compared to small banks, approximately a two percentage point more for every percentage point increase in capital requirements. Column (3) confirms

\footnotetext{
${ }^{41}$ Same categories for the breakdown of distance from OCR as in the previous section, as well as other categories of size of the bank have been experimented, the results are similar in terms of both magnitude and statistical significance, they are available from the author.

${ }^{42}$ Notice that netting out total assets from RWA eliminates also concerns on endogeneity due to reverse causality.
} 
further that banks do not decrease their assets size significantly following an increase in capital requirements.

In Column (4)-(6) we augment the specification with the risk weight measurement framework represented by the indicator variable for IRB, which takes the value one if the bank is using the internal rating based approach. Column (4) reveals that the increase in RWA is driven exclusively by banks with assets greater than USD 100 billions. The coefficient for large banks increased to eighteen percent following a one percentage point hike in capital requirements. The impact for smaller banks is no longer significant. More telling is the impact for banks with more than USD 100 billions in assets using the IRB approach, they appear to show less risk taking by sixteen percent less than large banks relying on the SA. It follows that the marginal impact of one percentage point increase of the SMCR on large IRB banks is only two percent increase in RWA.

Column (5) of Table 8 takes a closer look by netting out the confounding effect of the RWA ratio denominator. The first and the forth row of Column (5) confirm that even smaller banks take more risks following a rise in capital requirements while the IRB approach for small banks does not bring significant benefit in curtailing their risk ratio. For smaller banks, a one percentage point increase in capital requirements is associated with an increase of the risk ratio by 4.3 percentage points. More interestingly, the second and the third row of Column (5) suggests that there is a positive relation between risk taking behaviour and size when capital requirements are levied on banks. As the size of the bank increases, and with it its systemic importance, the risk taking behaviour is more accentuated. A one percentage point increase in capital requirements is associated with a 7.3 percentage points increase of the risk ratio for medium banks, and with a 9.6 percentage points increase for large banks, both at $5 \%$ significance level.

Can IRB banks reduce the observed risk taking behaviour by exploiting the more advanced approach to measure risk weights? The last row of Table 8 presents the results. For medium banks, the interaction coefficient between size and IRB is negative even if it is not statistically significant. Large IRB banks with total assets above USD 100 billions show a decrease of their risk ratio by 3.6 percentage points with respect SA banks of similar size. They show a significantly lower propensity to augment their risk ratio when capital requirements are incremented despite the marginal effect is still greater than the baseline banks with assets lower than USD 20 billions. This implies that large IRB banks are successful in presenting a reduced risk exposure to their supervisors, suggesting overall lower levels of risk taking. To what extent this risk reduction is real and effective, or is just the result of manipulating the risk weights in their own favor, it is impossible to discern with the data used in this paper. Nevertheless, the evidence establishes the presence of a competitive advantage for IRB banks since lower risk 
weights imply a lower cost of compliance to a hike of regulatory capital requirements. ${ }^{43}$

\subsection{Heterogeneity on Risk by Profitability, Funding and Leverage}

This section explores further the heterogenous impacts of a change in capital requirements on bank risk taking behaviour by looking at three measures of bank performance: net interest income as a proxy for profitability, wholesale funding as a proxy for inherent liquidity risk, and the leverage ratio as a measure of bank capitalization.

\subsubsection{Profitability and risk taking}

The low interest rate environment which characterisd the past decade shrinks the interest income margin of banks and increases pressure on their profitability. The literature has shown convincingly this link in both theoretical and empirical contributions, Samuelson (1945); Hancock (1985); Borio et al. (2017). Therefore, less profitable banks may take more risk in order to compensate for the reduced profitability. This argument is strictly intertwined with the proponents of the charter value theory of the bank, as summarized in Section 2, which support the skin in the game argument whereby banks have more incentives to operate conservatively when the amount of equity is at risk, Marcus (1984); Benston (1986).

If the above arguments are true, more profitable banks should show a less aggressive risk taking behaviour when faced with a capital increase. To test this proposition, the specification is augmented including an interaction of the SMCR and an indicator dummy of net interest income (NII) as a proxy for profitability. NII is defined as interest income less interest expense before provisions for loan losses, and hence is a direct measure of return stemming from interest rate. Table 9 presents the results for profitability in Columns (1)-(2). The dummy for profitability is switched on if net interest income is above median (NII $=1)$, reporting the estimates for more profitable banks.

The evidence suggest that there is a greater tendency to take on more risk by the cluster for less profitable banks. This finding is corroborated by the second block of rows in Table 9 which presents the evidence when the profitability dummy is turned on (NII $=1$ ). The coefficient estimated for small banks with a net interest income above the median has a positive albeit insignificant magnitude. The positive relationship may be due to a significant stock of non

\footnotetext{
${ }^{43}$ These result raise the question whether very big and sophisticated banks, the G-SIBs and their subsidiaries across Europe, are driving this behaviour. Unfortunately, all 14 G-SIB in our sample are sophisticated enough to adopt the IRB approach for risk weights measurement, this lack of variation does not permit to test this hypothesis. A solution is to use a higher threshold for the size of the very large banks and as a proxy rule we defined the threshold of USD 300 billions for the very big banks in the EU, but even in this case the required variation in the IRB variable was not sufficient to obtain the estimates, see Table A-I. Only three banks with assets greater than USD 300 billions adopt the SA and 29 use the IRB.
} 
performing exposures that are usually concentrated in smaller EU banks and that may induce small banks to take on more risk on their portfolios. ${ }^{44}$.

More interestingly, profitable medium and large banks show a significant reduction of the risk ratio with respect to similarly sized less profitable banks. Medium banks with above median net interest income decrease their risk ratio by 1.6 percentage points (s.d. 0.741) less than same sized banks with below median NII. The decrease in risk by profitable medium sized banks is compensating the greater propensity of medium banks to take on more risk. This leads to the conclusion that most of the increase of risk taking associated with bank size as shown in the previous section is due to less profitable banks. The same compensatory pattern in risk taking is observed for large profitable banks, they decrease the risk ratio by 2.01 percentage points (s.d. 0.925) with respect large banks with below median NII. For both median and large banks, a test of the sum of the coefficients for above and below median NII banks, fails to reject the null. ${ }^{45}$

These results confirm the fact that more profitable banks show a less aggressive risk taking behaviour when faced with a capital increase, and indicate that most of the increase in risk taking associated with size is related to less profitable institutions.

\subsubsection{Wholesale funding and risk taking}

This section introduces a link between liquidity risk and the risk taking behaviour. In general, banks with a greater reliance on market funding are more prone to liquidity runs in times of crisis, see Rajan (2006); Brunnermeier (2009). ${ }^{46}$ Wholesale funded banks have to frequently rollover large amounts of funds which makes them particularly vulnerable when market or interbank liquidity dries up. In addition, Huang and Ratnovski (2011) show how on the supply side of wholesale funding the financiers do not have incentives to conduct costly monitoring of banks since they may withdraw on short notice based on negative news signals, exacerbating further the risk of a potential bunk run. This inherent liquidity risk residing in wholesale funded banks poses a threat to their stability.

Based on the evidence provided in previous sections the question arises as to whether wholesale funded banks recognize the inherent liquidity risk of their funding model when reacting to a hike in regulatory capital or not. If not, the consequences of an increase in capital requirement from a systemic standpoint may be even more worrisome since higher risk taking is more likely to lead to negative news signals and subsequent bunk runs.

\footnotetext{
${ }^{44}$ For the NPL ratio by size class see EBA Risk Dashboard

${ }^{45}$ For median banks the null hypothesis of the linear combination $2.158-1.634=0$ has a p-value $=0.63$ and fails to reject the null. For large banks the tested linear combination is $2.842-2.067=0$ with a resulting $p$-value $=0.48$

${ }^{46}$ For instance, Shin (2009) notes that in the Northern Rock bank run case, wholesale funding plummeted by more than $50 \%$, from 26.7 billion pounds in June to 11.5 billion pounds in December 2007.
} 
The evidence on the interaction between wholesale funding model and risk taking behaviour following an increment of the SMCR is provided in Column (3)-(4) of Table 9. Wholesale funded banks are coded with a dummy being one when the ratio of wholesale funding, short and long term, over total assets is greater than the median. The first three rows corroborate the results observed in previous specifications. Medium and large banks show more than 2 percentage points higher reaction of the risk ratio than smaller banks. The results however change significantly when the SMCR increase is interacted with a dummy for wholesale funded banks (WHS=1) and the size of banks. Smaller wholesale funded banks present a further increase in the risk ratio by 1.34 percentage points with respect to similar size non wholesale funded banks. On the contrary, medium and large wholseale funded banks decrease their risk ratio by the same amount of their risk increase after the hike in capital requirements.

This reduction compensates the propensity to rise the risk ratio associated with medium and large banks and indicates that the increase of the risk ratio is largely driven by bigger banks not predominantly funded on the wholesale market. The results also suggest that wholesale funded banks may have a lower incentive to increase the riskiness of their portfolio when faced with a capital requirement hike. This may be due to several factors and in particular can be interpreted as a strategic need to reduce the observable risk ratio in view of the already riskier funding model.

A further interpretation may be related to profitability and the results in Column (3)-(4) on wholesale funding can be reconciled with the evidence provided in the previous section on profitability and risk taking, see Columns (1)-(2). In fact, recent literature has shown that wholesale funded banks have a competitive advantage in a low interest rate environment since they can shift their funding globally towards regions where monetary policy conditions are looser and exploit thus cross-border funding to limit the negative pressure on profitability due to low interest rates, see Bruno and Shin (2015). It follows that wholesale banks are on average more profitable than banks relying on standard deposit funding, this is described in Figure 1 for our sample of G-SIBs and O-SIBs in the EU, and therefore have lower incentives to increase their riskiness to compensate for lower interest income.

\subsubsection{Leverage and risk taking}

This section investigates the link between leverage and risk taking as evidenced by Furlong and Keeley (1989) and Dewatripont et al. (1994). Leverage is measured following the Bank of International Settlements definition by dividing Tier 1 capital by the bank's average total consolidated assets (i.e. the sum of the exposures of all assets and non-balance sheet items). ${ }^{47}$ In

\footnotetext{
${ }^{47}$ For more detailed information on the Basel III leverage ratio consult the documentation provided on the BIS website
} 
addition, a dummy variable is defined for above $(\mathrm{LR}=1)$ or below $(\mathrm{LR}=0)$ the median leverage ratio in the sample. The evidence for the interlinkages between leverage and risk taking subject to a regulatory capital increase is presented in Columns (5)-(6) of Table 9.

While the first three rows confirm again the incremental impact of regulatory capital on the risk taking behaviour by bank size, the heterogeneous impact by above median leverage ratio is not statistically significant. The sign of the interaction coefficients for medium and large banks hints at a negative relationships, however the estimates are rather noisy suggesting an absence of relationship between risk taking and leverage ratio following an increase in regulatory capital requirement. This result is consistent with the evidence shown in the baseline regression for risk taking presented in Table 6 where the impact was broken down by the distance from the minimum overall capital requirement. Despite the distance from OCR being a risk-sensitive measure of capital due to the use of risk-weighted assets at the denominator, it is positively correlated (correlation coeff. $=0.35$ ) with the non-risk-based leverage ratio measure and has a similar economic interpretation.

\section{Robustness}

\subsection{Common bank-level trends}

Two-way Difference-in-difference (DiD) models hinge on the assumption of parallel trends, Angrist and Pischke (2008), in the current setting this assumption implies that the risk taking behaviour of both treated and not treated banks would be same in absence of treatment. This section presents the evidence of two standard tests of the common trend assumption for DiD regressions. The first test controls for bank-level trends in the regression, the second test the existence of anticipatory behaviour by some banks which would invalidate the common trend assumption. $^{48}$

\subsubsection{Bank trends and longer time frame}

The first test studies the influence of confounding pre-existing trends on the estimated coefficient by including a bank specific trend in the model. This is a simple method and allows to control

\footnotetext{
${ }^{48} \mathrm{It}$ is useful to note the difference between the standard two-way DiD setting in which two groups (treated vs non-treated) are compared and the treatment variables is a dummy $(1 / 0)$, and the DiD setting in this paper the where multi-groups (i.e. banks) are compared and the intensity of treatment varies across banks, i.e. the treatment variable is not a simple dummy but varies across banks. In addition, in this study the time dimension is not constituted by only two periods (after/before) as in the standard two-way DiD approach, instead each quarter after the beginning of the phasing in of macroprudential capital requirements can have a different level of treatment per bank introducing thus a more dynamic multi-period treatment.
} 
for the diverging trends across banks, that is at the level of the change of the policy variable. ${ }^{49}$ It is also important to note that when pre-existing trends are correlated with both the change in capital requirements and the risk taking behaviour of banks, the inclusion of bank specific trends in the model ensures that the estimated coefficient is not affected by omitted variable (i.e. trend) bias, see Wolfers (2006).

Formally, to test for the robustness of the inclusion of bank trends the baseline model is augmented with bank specific trends represented by the product $\phi_{i} \cdot t$ where $i$ is the indicator for banks and $t$ stands for the time dimension (i.e. quarters):

$$
\ln Y_{i c t}=\alpha_{i}+\beta \Delta S M C R_{i c t}+\ln X_{i c, t-1} \gamma+\phi_{i} \cdot t+\delta_{c t}+u_{i c t}
$$

If the impact of the increment in capital requirements on the risk ratio found in the previous sections is not statistically significant after including bank-level trends then the evidence presented should be interpreted with caution. In that case, it is very likely that divergent trends would affect the findings because the increment in capital requirements would have happened predominantly in banks where already an rising risk ratio was being implemented by bank management, as such the association of risk taking with the change in policy would be confounded by pre-existing trend and hence spurious.

The evidence for the first test on common trends is illustrated in Table 10. The Table is split in two parts, Columns (1)-(3) present the results for capital to be compared with baseline regression without bank specific trend as in Table 5; Columns (4)-(6) presents the results for risk taking behaviour to be compared with baseline Table 6. After including bank specific trends the results remain substantially unchanged for both capital and risk taking while the coefficient of determination R-squared is considerably higher since data now explain a greater portion of the variation of dependent variables. As common when trends at the policy variable are included standard errors are larger implying a higher p-value. The coefficients on the level of CET1 and total capital are slightly smaller than in the baseline regressions. The coefficient on the risk ratio decreases the most after including bank trends, the impact of higher capital requirement on risk taking results halved to 3.1 percentage point increase for a one percentage point increase of the SMCR. While this is a considerable reduction of risk taking, overall the results from the baseline specification are confirmed.

It is important to notice that the estimated trends may depend on the length of the time series. In fact, as shown in Wolfers (2006), controlling for bank specific trends only works well when there is a sufficient sample period available before the treatment period commences. As

\footnotetext{
${ }^{49}$ See Angrist and Pischke (2008). Trends in risk taking behaviour may diverge because of several reasons: for instance structural changes in bank business models or because of the formation of expectations on future regulation as for example the introduction of new provision within Basel IV that may affect strategic portfolio allocation of banks.
} 
such, the estimated trends in Equation 3 may require more observations to be properly fitted to the data. The problem is exacerbated when there is a structural break in the pre-existing trend of the outcome variable as it is likely to have happened after the 2007-8 financial crisis as shown for capital in Figure 2. The test is therefore repeated extending the estimation sample to begin in 2006 rather than in 2010. This allows to estimate bank specific trends on a full financial cycle before starting in 2006 before the financial crisis and ending with the introduction in 2014 of macroprudential capital buffers controlling thus for structural changes in trends of outcome variables.

Each plot of Figure 3 shows the evolution of the $\beta$ coefficient in Equation 3 when the sample has a different starting year. Each plot shows the evolution of the impact of higher capital requirement when the bank trend is estimated with progressively shorter time frames. The first column of Figure 3 presents the evidence for capital variables with one plot each for CET1 ratio, CET1 capital and total capital. The second column illustrates the evidence for risk with one plot for RWA, the risk ratio and total assets. From left to right in each plot, the dots represent different $\beta$ s estimated when increasing the starting period of the sample by one year progressively and shrinking thus the available observations for the estimation of the trend. Vertical bars show confidence intervals for every estimated $\beta$.

In conclusion, the assumption of common trends is also robust to different starting initial years of the sample which allow for a better fit of pre-existing trends to the data. In particular, the risk ratio and the RWA show similar estimated coefficients as in Table 10. The level of CET1 is however not always significant when the trend is allowed to be computed prior to 2010 (the failure to accept is due to few decimals of a percentage points) indicating that the results for the level of CET1 may suffer from the common trend assumption.

\subsubsection{Anticipation effects}

An additional method to test for common trends when treatment changes across several years is to use leads of the policy variable. If leads of SMCR turn out to be significant, there may be differential pre-treatment trends across the banks, due for example to anticipation effects, and the assumption of common trends would be questioned. In that case, the findings in the previous sections may not be considered as a causal effect but causality may instead run in opposite direction.

Figure 2 shows the dynamics of the supply of capital for systemically important banks in the EU. The Common Equity Tier 1 (CET1) capital ratio of SIBs increased by more than 6 percentage points since 2010 with strongest increase occurring in 2013 when the EU CRDIV/CRR regulation was officially transposed into law. This may suggest that EU banks could have anticipated a tighter macroprudential policy stance by raising capital ratios. To test the antic- 
ipation effects the baseline specification is enriched with two year leads of the policy variable. Formally:

$$
\ln Y_{i c t}=\alpha_{i}+\sum_{q=0}^{8} \beta \Delta S M C R_{i c, t+q}+\ln X_{i c, t-1} \gamma+\delta_{c t}+u_{i c t}
$$

Table 11 summarises the evidence for capital in Columns (1)-(3) and risk in Columns (4)(6). The one and two years leads are computed summing the coefficients of the four quarters prior to policy change, and standard errors are adjusted accordingly.

The results in Table 11 present some novelties: Column (1) reveals that banks adjust their capital ratio already one year prior to the policy change, probably as a signalling effect to the markets. This adjustment seems to be driven by a deleveraging policy via a reduction of total assets, see Column (6).

Importantly, none of the main results of previous section is affected by the introduction of leads in the specification. The level of CET1 is statistically significant only at the time of the policy change. The same holds for RWA and the risk ratio in Columns (4)-(5). Overall, the findings indicate that banks in the sample had comparable pre-intervention trends for the level of CET1 capital and the risk ratio.

\subsection{Announcement effects}

The announcement of a change in the capital requirements policy may itself lead to strategic reactions by banks. The European Commission anticipated publicly the intention to strengthen its capital framework for systemically important banks already in September 2009 when introducing the possibility to increase macroprudential capital buffers in good times and released in a downturn. ${ }^{50}$ This change of paradigm may have induced strategic reactions by banks and may confound the previous findings since the largest banks in the EU may have anticipated the policy change and increased capital and/or risk during the announcement period prior to the activation phase.

In order to test formally for the impact at the announcement of the change in macroprudential policy this section relies on an event analysis framework akin to Alpert (2016). The basic strategy compares deviations from trends of capital and risk taking for a treatment group of banks with the deviation from trends for a control group of banks during the announcement period. If the deviations are statistically significant then the common trend assumption across the two groups would not hold.

\footnotetext{
${ }^{50}$ The proposed changes were introduced under the Commission Directive 2009/111/EC of the European Parliament and of the Council of 16 September 2009 amending Directives 2006/48/EC, 2006/49/EC and $2007 / 64 / \mathrm{EC}$ as regards banks affiliated to central institutions, certain own funds items, large exposures, supervisory arrangements and crisis management. A copy of this directive may be found at this link
} 
In the following, the announcement period is defined as the period from 2009Q4 until 2013Q4. To define the treatment group a dummy takes the value of one if the bank has been subject to a specific structural macroprudential capital buffer (i.e. G-SIB, O-SIB or SRB) in any quarter after 2014q1. Such coding ensures that banks cannot self-select in the treatment group since the decision to levy a capital requirement on a specific banks is taken by the policy maker. At the same time, the treatment group of banks may reasonably expect to be part of the group of systemically important banks and expect to be subject to a future capital increase after the announcement, and may react in advance to the shift in the macroprudential paradigm, implying a breach of the common trend assumption. To test for this hypothesis, variants of the following $\mathrm{DiD}$ equation which includes the announcement period dummy are estimated:

$$
\begin{aligned}
\ln Y_{i c t}=\alpha_{i} & +\beta \Delta S M C R_{i c t}+\omega D(\text { Announcement }) * D(\text { Treated })+\ln X_{i c t-1} \gamma+ \\
& +\eta D(\text { Announcement })+\theta D(\text { Treated })+\delta_{c t}+u_{i c t}
\end{aligned}
$$

The results are presented in Figure 4 for the level of CET1 capital and in Figure 5 when the dependent variable is the risk ratio. The left panels of each figure show the $\omega$ coefficient of the interaction term $D$ (Announcement) $* D$ (Treated) for different starting periods of the estimation sample similar to the reasoning of Table 3. The right panels of each figure plot the $\beta$ coefficient for $\triangle S M C R_{\text {ict }}$ as specified in Equation 5.

For either capital or risk indicators, the evidence indicates that there is generally no statistically significant difference in the reaction of treatment banks during the announcement period and in comparison to the non-treated group. For the risk ratio, and only when the sample begins in 2006, the impact is significant at the ten percent confidence level. The impact of the SMCR in the implementation period, i.e. after 2014, remains in line with the coefficient found in the baseline Tables 5 and 6 . In other words, the impact of the SMCRs is not absorbed or curtailed by the introduction of a dummy that captures the announcement period and we can conclude that the estimated positive relationship between higher capital requirements and higher capital and risk taking is robust to the inclusion of announcement periods. ${ }^{51}$

\section{Solvency: Probability of Default}

This section explores the impact of a hike in capital requirements on the solvency of financial institutions. As shown previously, the tightening of the capital requirements has two opposing

\footnotetext{
${ }^{51}$ Alternative later periods may be considered as the beginning of the new macroprudential framework in the EU as for instance since the EU Commission public consultation on the new CRD-IV in 2010Q2. Nevertheless, similar results to those presented in Figures 4 and 5 are obtained when the announcement period is set in 2010Q2. Results are available from the author. The document of the consultation is available at this link.
} 
effects: i) results of Section 5.1 would suggest that higher capital requirements would make banks more solvent and, consequently, reduce their probability of default; ii) at the same time, the findings in Section 5.2 show that higher capital requirements may lead to moral hazard and increased risk-taking, thus weakening banks solvency. Hence, the net impact of the two opposing effects on bank's probability of default is ambiguous.

In order to shed light on which of the two opposing effects on solvency is stronger, this section uses credit ratings as a gauge of banks' probabilities of default. The default probabilities are extrapolated from bank issuer ratings provided by three major rating agencies. ${ }^{52}$ The probabilities of default are obtained by mapping and converting of alphanumeric ratings using publicly available conversion tables on rating agencies websites. The constructed distance to default variable informs about the solvency of a bank by estimating the default probability over the next, two, three, four and five years. It provides timely information reflecting current market perception, and summarises market-wide information on the drivers of default probability.

Similarly to Section 4.2, the phasing-in of SMCR in the EU is used as a tool for a controlled comparison whereby different institutions across Europe are subject to heterogenous intensity of capital requirements. However, this section departs fundamentally from the previous estimates since the dependent variable is now part of the reaction function of market agents to higher capital requirements and not a reaction of the bank itself. Results are presented in Table 12. The table presents in each column the evidence for a different probability of default horizon. Estimates are broken down by the size of the bank. The first thing to notice is that the sample size decreased due to the limited availability of ratings for some banks with respect to the capital and risk ratio regressions, the consequence is that results should be interpreted with an additional ounce of caution for external consistency. ${ }^{53}$

The evidence shows that the market reaction to higher capital requirements is bringing some benefits to medium and large banks in terms of reduced probability of default but only with respect to smaller banks. The relative impact is slightly greater for banks with total assets above USD 100 millions, and increasing in the probability of default horizon for both medium and large banks. Depending on the maturity horizon of the probability of default, medium and large banks have a lower probability of default with respect to small banks, i.e. 1.3-2.0 percentage points lower for a one percentage point increase in capital requirements. This result suggests that, relative to small banks, for medium and large banks the effect of the increase in CET1 capital is stronger than the risk taking channel.

\footnotetext{
${ }^{52}$ The rating agencies are Fitch, Moody's and S\&Ps

${ }^{53}$ An alternative market based measure of banks' solvency are CDS prices. Nevertheless, contrary to the ratings, the scope of application of CDS pricing is very limited in our sample since CDS prices are generally available only for some of the large systemic banks. In our sample, this translates to 49 banks with available CDS prices which is much less than the number of clusters in previous regressions. The use of CDS prices would thus create a sample composition bias relative to previous estimates.
} 
Nevertheless, the marginal effects for medium and large banks, while having a negative sign, is not statistically significant as shown in the second panel of Table 12. For instance for the one year horizon, the marginal effect of a one percentage point increase in capital requirements for large banks is -0.938 (st.dev. 0.900). While this indicates that the rating agencies may tend to assess the capital increase channel to be stronger, this assessment cannot be statistically corroborated. Similar results are obtained for the marginal effects at different time horizons and for medium sized banks. ${ }^{54}$

The evidence on leads to conclude that the increase of capital requirements does not improve banks' probability of default in absolute terms. In other words, the positive effect of accumulating more equity capital is counterbalanced by the negative substitution effect toward more riskier assets, so that the overall net effect on solvency is zero. This raises a concern for the policy maker since the improved resilience achieved by demanding higher capital requirements can be crowded-out by an increase in risk taking.

\section{Conclusions}

The paper presents empirical evidence on the reaction of systemically important EU banks to a hike in capital requirements. Endogeneity concerns related to the change in capital requirement may arise since these are set at a country level. These are, however, alleviated by several provisions within the EU banking regulation mitigating considerably the influence of national interest.

The evidence shows that the impact for O-SIBs and G-SIBs contributed to a substantial increase of CET1 capital levels in the EU banking sector. In response to the implementation of the new legislative package, the overall capital levels, and hence the solvency and the loss absorption capacity, of European systemically important banks increased. This would likely translate in a strengthened resilience of the EU banking sector and would presumably sustain credit growth in a downturn of the financial cycle. The building of capital buffers would limit also the cost to the taxpayer when next bank bankruptcies occur.

At the same time, the paper documents some unintended consequences of bank regulation, which promoted a pronounced risk-taking behaviour by banks suggesting that banks tend to exploit moral hazard when faced with higher capital requirements. This result indicates that there is a risk-capital trade-off: if banks consider that higher regulatory requirements can hinder further their profitability prospects, they will invest in potentially more profitable but

\footnotetext{
${ }^{54}$ This is further confirmed by a baseline regression of the probability of default without the dummy for size, and those broken down by the distance from the OCR, the net interest income and wholesale funding dummies. All of them do not have statistically significant results at standard confidence levels, these specifications are available from the author.
} 
riskier assets. This finding is in particular true for less profitable and large banks, while the paper documents that banks adopting the IRB approach mitigate somewhat this effect and wholsesale funded banks also show lower risk taking possibly due to a strategic need to reduce the observable risk in view of the already fragile funding position.

The paper shows that the net impact of the two opposing effects on banks solvency is not statistically different from zero. In other words, the increased risk taking is compensating the positive results on solvency arising from higher shareholders' capital so that the net effect on banks' probabilities of default is insignificant.

This raises the question as to how policy intervention should aim at constraining bank's risktaking behaviour. While several suggestions are being currently discussed in the regulatory and policy fora, it is important to keep in mind that introducing policies to lower risk-taking may create further perverse incentives for banks. For instance, it can promote a more systematic use of internal rating based models, or it can induce banks to shift risks to off-balance sheet exposures. The regulatory task is not a simple one, any policy change requires a comprehensive assessment of hidden incentives behind regulatory action. 


\section{References}

Acharya, V. and Naqvi, H. (2012). The seeds of a crisis: A theory of bank liquidity and risk taking over the business cycle. Journal of Financial Economics, 106(2):349-366.

Acharya, V. V. (2009). A theory of systemic risk and design of prudential bank regulation. Journal of financial stability, 5(3):224-255.

Alexander, K. (2006). Corporate governance and banks: The role of regulation in reducing the principal-agent problem. Journal of Banking Regulation, 7(1-2):17-40.

Alpert, A. (2016). The anticipatory effects of medicare part d on drug utilization. Journal of health economics, 49:28-45.

Angrist, J. D. and Pischke, J.-S. (2008). Mostly harmless econometrics: An empiricist's companion. Princeton university press.

BCBS (2013). Global systemically important banks-updated assessment methodology and the higher loss absorbency requirement. Bank for International Settlements.

Benston, G. J. (1986). Perspectives on Safe ES Sound Banking: Past, Present, and Future. Cambridge, Mass.: MIT Press.

Berger, A. N. (1995). The relationship between capital and earnings in banking. Journal of money, credit and Banking, 27(2):432-456.

Blum, J. (1999). Do capital adequacy requirements reduce risks in banking? Journal of Banking Ef Finance, 23(5):755-771.

Bolton, P., Mehran, H., and Shapiro, J. (2015). Executive compensation and risk taking. Review of Finance, 19(6):2139-2181.

Borio, C., Gambacorta, L., and Hofmann, B. (2017). The influence of monetary policy on bank profitability. International Finance, 20(1):48-63.

Brealey, R. (2006). Basel ii: The route ahead or cul-de-sac? Journal of Applied Corporate Finance, 18(4):34-43.

Brunnermeier, M. K. (2009). Deciphering the liquidity and credit crunch 2007-2008. Journal of Economic perspectives, 23(1):77-100.

Bruno, V. and Shin, H. S. (2015). Capital flows and the risk-taking channel of monetary policy. Journal of Monetary Economics, 71:119-132. 
Calomiris, C. W. and Jaremski, M. S. (2016). Stealing deposits: deposit insurance, risk-taking and the removal of market discipline in early 20th century banks. Technical report, National Bureau of Economic Research. The article is forthcoming in The Journal of Finance.

Dewatripont, M., Tirole, J., et al. (1994). The prudential regulation of banks. Technical report, ULB-Universite Libre de Bruxelles.

Diamond, D. W. and Dybvig, P. H. (1983). Bank runs, deposit insurance, and liquidity. Journal of political economy, 91(3):401-419.

Flannery, M. J. (1989). Capital regulation and insured banks choice of individual loan default risks. Journal of Monetary Economics, 24(2):235-258.

Furlong, F. T. and Keeley, M. C. (1989). Capital regulation and bank risk-taking: A note. Journal of banking $\&$ finance, 13(6):883-891.

Galai, D. and Masulis, R. W. (1976). The option pricing model and the risk factor of stock. Journal of Financial economics, 3(1-2):53-81.

Gennotte, G. and Pyle, D. (1991). Capital controls and bank risk. Journal of Banking $\mathscr{G}$ Finance, 15(4-5):805-824.

Green, R. C. (1984). Investment incentives, debt, and warrants. Journal of financial Economics, 13(1):115-136.

Gropp, R., Mosk, T., Ongena, S., and Wix, C. (2016). Banks response to higher capital requirements: Evidence from a quasi-natural experiment. The Review of Financial Studies.

Haldane, A. G. and May, R. M. (2011). Systemic risk in banking ecosystems. Nature, 469(7330):351.

Hancock, D. (1985). Bank profitability, interest rates, and monetary policy. Journal of Money, Credit and Banking, 17(2):189-202.

Haubrich, J. and Wachtel, P. (1993). Capital requirements and shifts in commercial bank portfolios. Economic Review, (Q III):2-15.

Hellmann, T. F., Murdock, K. C., and Stiglitz, J. E. (2000). Liberalization, moral hazard in banking, and prudential regulation: Are capital requirements enough? American economic review, pages $147-165$.

Hellwig, M. (1995). Systemic aspects of risk management in banking and finance. Swiss Journal of Economics and Statistics (SJES), 131(IV):723-737. 
Hellwig, M. et al. (2010). Capital regulation after the crisis: Business as usual? Technical report, Max Planck Institute for Research on Collective Goods.

Huang, R. and Ratnovski, L. (2011). The dark side of bank wholesale funding. Journal of Financial Intermediation, 20(2):248-263.

Jacques, K. and Nigro, P. (1997). Risk-based capital, portfolio risk, and bank capital: A simultaneous equations approach. Journal of Economics and business, 49(6):533-547.

Jensen, M. C. and Meckling, W. H. (1976). Theory of the firm: Managerial behavior, agency costs and ownership structure. Journal of financial economics, 3(4):305-360.

Jiménez, G., Ongena, S., Peydró, J. L., and Saurina, J. (2016). Macroprudential policy, countercyclical bank capital buffers and credit supply: Evidence from the spanish dynamic provisioning experiments. Journal of Political Economy.

Kahane, Y. et al. (1977). Capital adequacy and the regulation of financial intermediaries. Journal of Banking \& Finance, 1(2):207-218.

Kareken, J. H. and Wallace, N. (1978). Deposit insurance and bank regulation: A partialequilibrium exposition. Journal of Business, pages 413-438.

Keeley, M. C. (1990). Deposit insurance, risk, and market power in banking. The American economic review, pages 1183-1200.

Kim, D. and Santomero, A. M. (1988). Risk in banking and capital regulation. The Journal of Finance, 43(5):1219-1233.

Koehn, M. and Santomero, A. M. (1980). Regulation of bank capital and portfolio risk. The Journal of Finance, 35(5):1235-1244.

Marcus, A. J. (1984). Deregulation and bank financial policy. Journal of Banking $\&$ Finance, $8(4): 557-565$.

Merton, R. C. (1977). An analytic derivation of the cost of deposit insurance and loan guarantees an application of modern option pricing theory. Journal of Banking \& Finance, 1(1):3-11.

Modigliani, F. and Miller, M. H. (1958). The cost of capital, corporation finance and the theory of investment. The American economic review, 48(3):261-297.

Rajan, R. G. (2006). Has finance made the world riskier? European Financial Management, 12(4):499-533. 
Repullo, R. (2004). Capital requirements, market power, and risk-taking in banking. Journal of financial Intermediation, 13(2):156-182.

Repullo, R. and Saurina, J. (2011). The countercyclical capital buffer of basel iii: A critical assessment. Technical report, CEMFI.

Repullo, R. and Suarez, J. (2004). Loan pricing under basel capital requirements. Journal of Financial Intermediation, 13(4):496-521.

Rime, B. (2001). Capital requirements and bank behaviour: Empirical evidence for switzerland. Journal of Banking \& Finance, 25(4):789-805.

Rochet, J. (1992). Capital requirements and the behaviour of commercial banks. European Economic Review, 36(5):1137-1170.

Ross, S. A. (1973). The economic theory of agency: The principal's problem. The American Economic Review, 63(2):134-139.

Samuelson, P. A. (1945). The effect of interest rate increases on the banking system. The American economic review, 35(1):16-27.

Saunders, A., Strock, E., and Travlos, N. G. (1990). Ownership structure, deregulation, and bank risk taking. The Journal of Finance, 45(2):643-654.

Schepens, G. (2016). Taxes and bank capital structure. Journal of Financial Economics, 120(3):585-600.

Shin, H. S. (2009). Reflections on northern rock: The bank run that heralded the global financial crisis. Journal of economic perspectives, 23(1):101-19.

Shrieves, R. E. and Dahl, D. (1992). The relationship between risk and capital in commercial banks. Journal of Banking \& Finance, 16(2):439-457.

Stiglitz, J. E. and Weiss, A. (1981). Credit rationing in markets with imperfect information. The American economic review, 71(3):393-410.

Wiseman, R. M. and Gomez-Mejia, L. R. (1998). A behavioral agency model of managerial risk taking. Academy of management Review, 23(1):133-153.

Wolfers, J. (2006). Did unilateral divorce laws raise divorce rates? a reconciliation and new results. The American Economic Review, 96(5):1802-1820. 
Figure 1: Profitability and Wholesale Funding

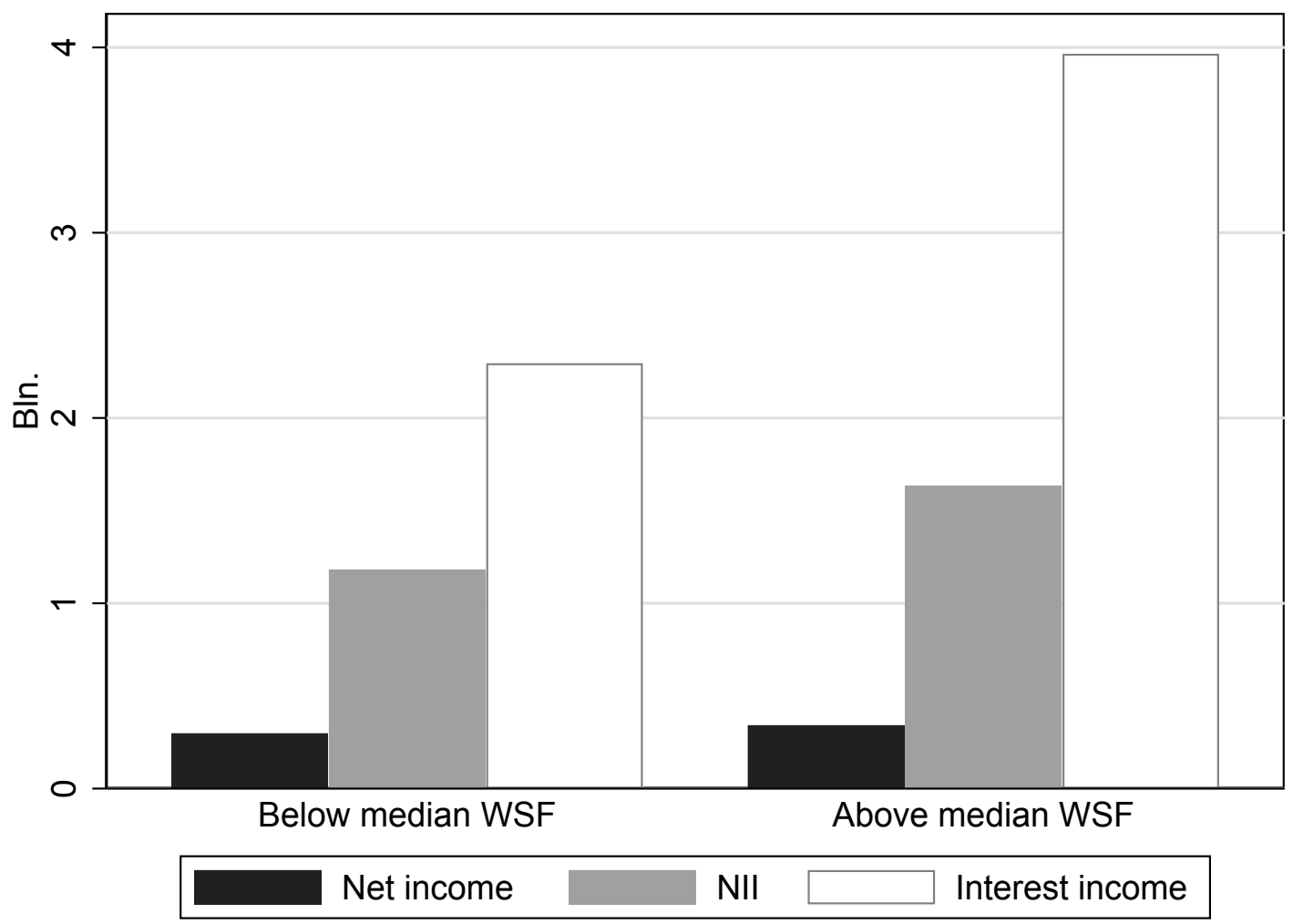

Note: the bar chart show some profitability measures broken down by above and below median wholesale funding reliance. For profitability it is used net overall income, net interest income (NII) and total interest income. A standard test of mean difference is run separately for the three income variables in a pooled panel. They are regressed on a dummy for wholesale funding above median. For net interest income and interest income the estimated $\beta$ coefficients are both significant and respectively 0.45 (s.d. 0.091) and 1.67 (s.d. 0.182) where standard errors are robust to heteroschedasticity and serial correlation. The coefficient on mean difference for net income is 0.04 (s.e. 0.035 ) and thus not statistically significant. 
Figure 2: The longer term trend of Capital

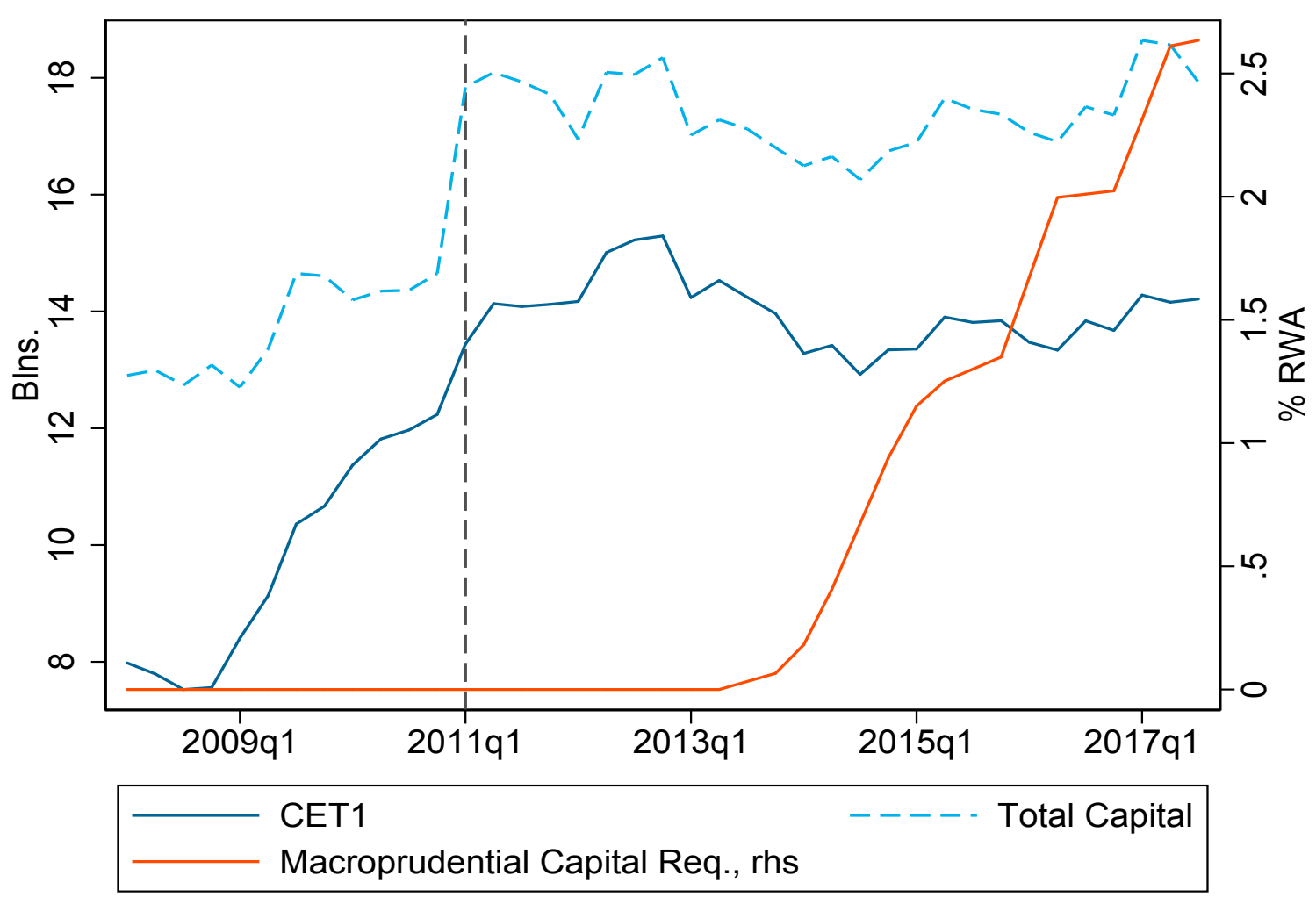

Note: The plot illustrates the evolution of the average CET1 and Total capital across the systemically important banks in the EU. The dashed line shows the moment of a break in the upward trend until $2011 \mathrm{Q} 1$. 
Figure 3: Robustness: the impact on Capital and Risk after controlling for bank specific trends
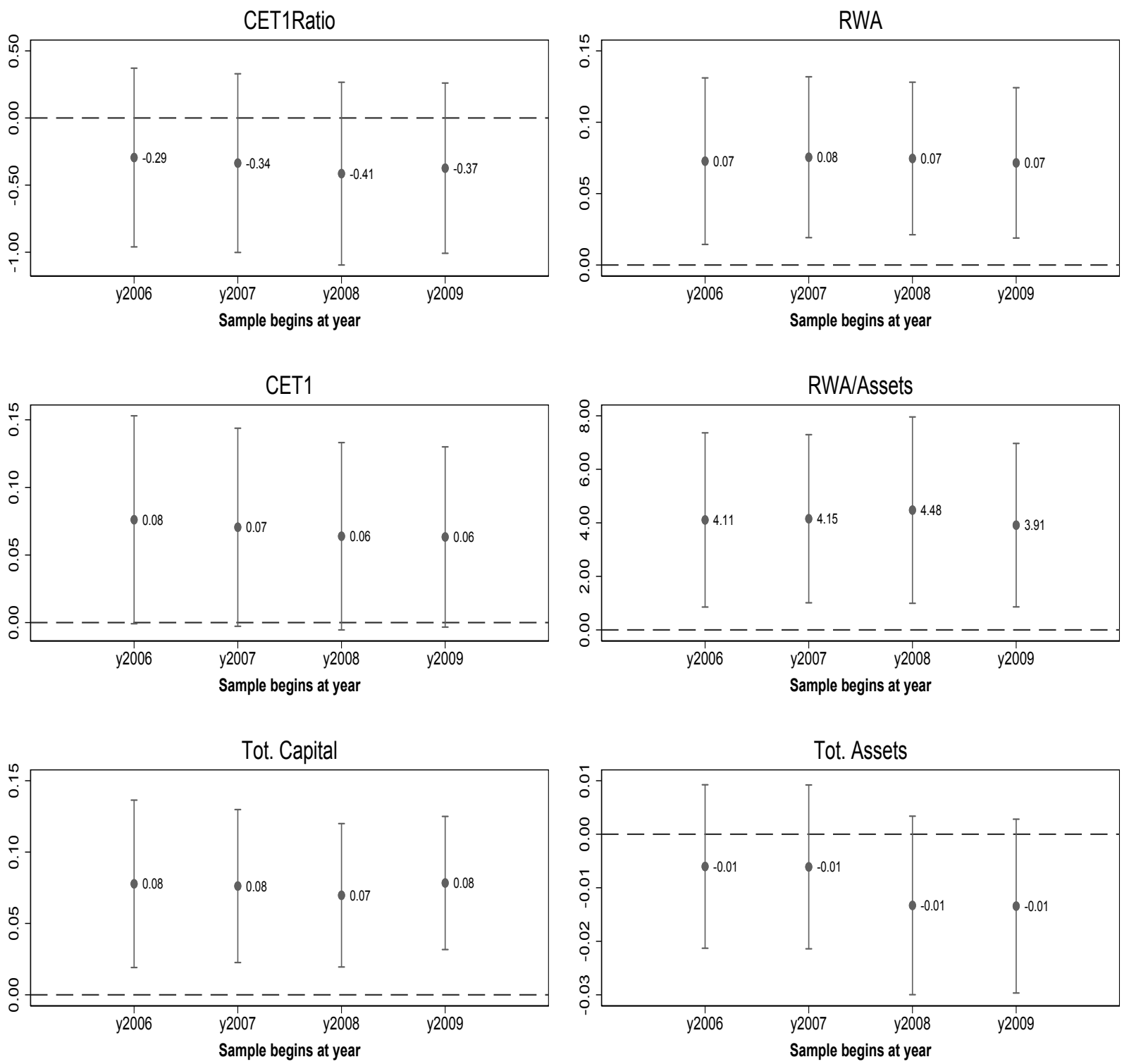

Note: The figure shows the evolution of the $\beta$ coefficient of equation 3 when the estimation sample is progressively reduced by one year. All models have bank trends included in the specification. On the horizontal axis every point represents the staring year of the respective estimation sample, for each sample the last quarter is 2017Q3. Moving to the right of each plot the sample period shrinks by one year each time and hence there are less observations available to compute bank-level trends. On the y-axis, the coefficients represent the impact of a hike in the macroprudential capital requirement. Vertical bars represent confidence interval at 10\% significance level. Standard errors are clustered at bank-level and robust for serial correlation and heteroschedasticity. 


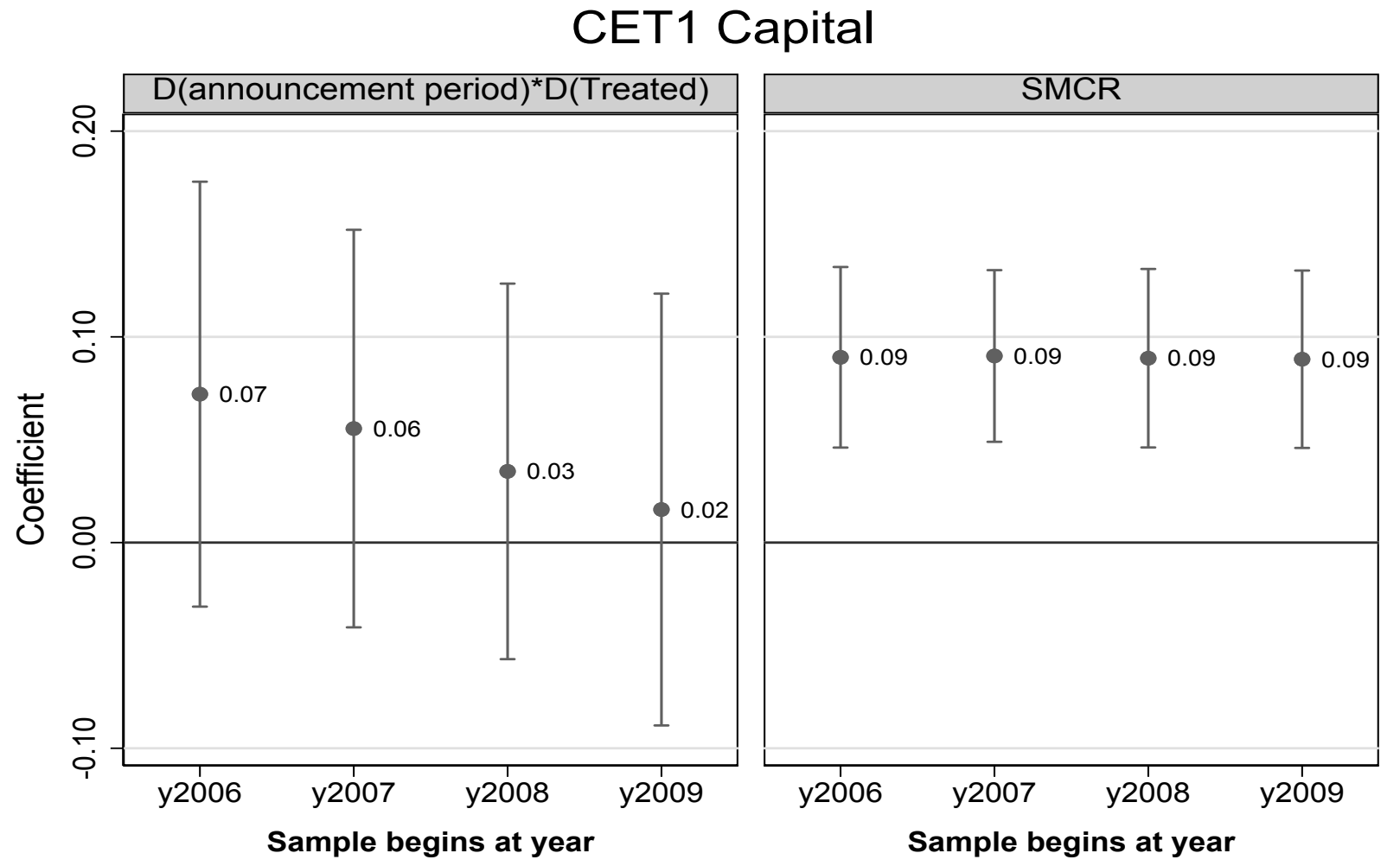

Note: The graph shows the evolution of $\omega$ and $\beta$ coefficients of equation 5 when the dependent variable is the level of CET1 Capital. The estimation sample is progressively reduced by one year, notice that for each sample the last quarter used in all regressions is 2017Q3. The announcement period is represented by a dummy for the period between 2009Q4-2013Q4, that is since the publication of the EU Commission Directive 2009/111/EC of the European Parliament and of the Council of 16 September pre-announcing a change in macroprudential regulation in the EU. Vertical bars represent confidence interval at 10\% significance level. Standard errors are clustered at bank-level and robust for serial correlation and heteroschedasticity. Similar results are obtained when the regressions control for bank specific trends, these results are available from the author. 
Figure 5: Robustness: Announcement effect of EU macroprudential policy on the Risk Ratio

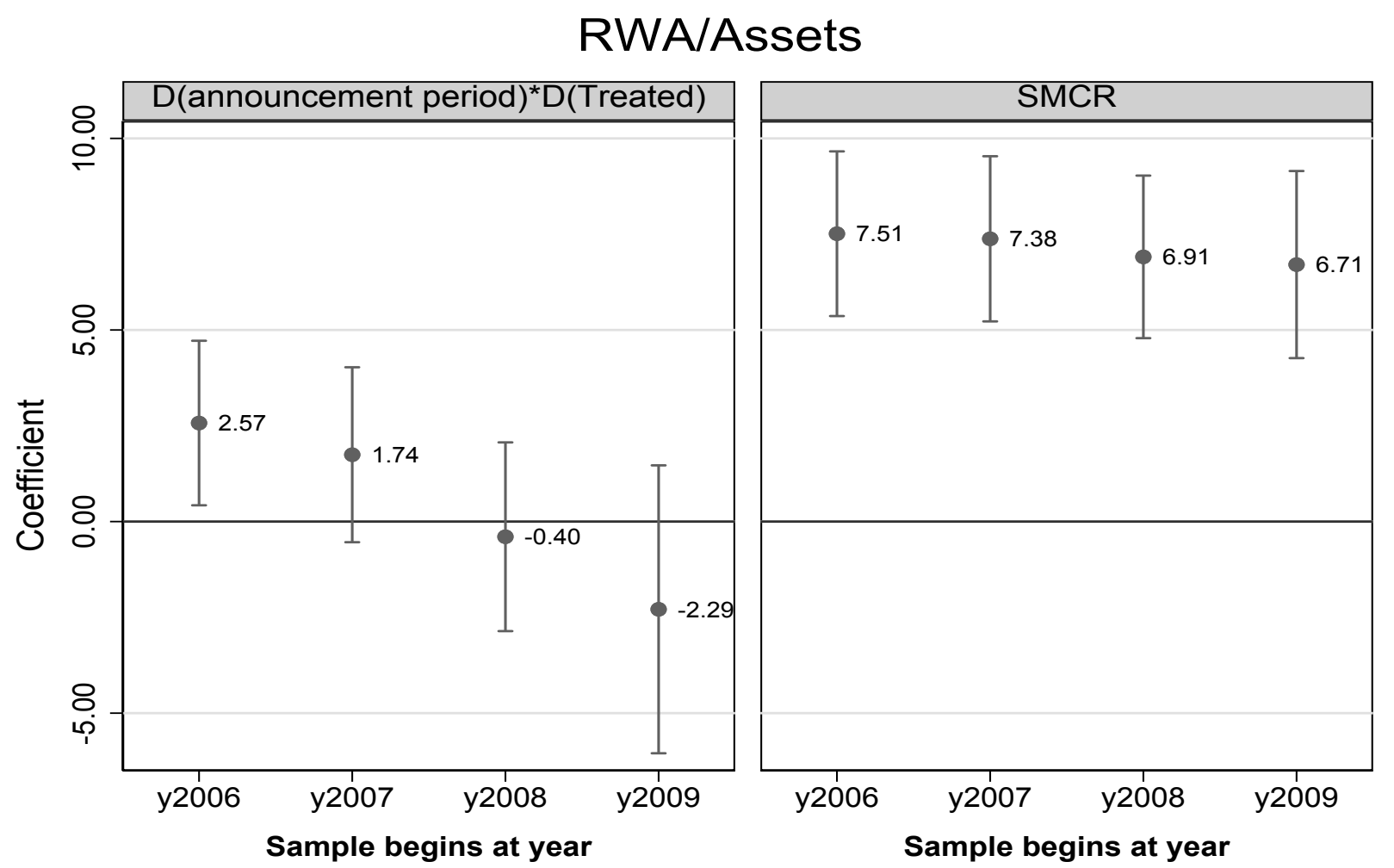

Note: The graph shows the evolution of $\omega$ and $\beta$ coefficients of equation 5 when the dependent variable is the risk ratio (i.e. RWA/Assets). The estimation sample is progressively reduced by one year, notice that for each sample the last quarter used in all regressions is 2017Q3. The announcement period is represented by a dummy for the period between 2009Q4-2013Q4, that is since the publication of the EU Commission Directive 2009/111/EC of the European Parliament and of the Council of 16 September pre-announcing a change in macroprudential regulation in the EU. Vertical bars represent confidence interval at 10\% significance level. Standard errors are clustered at bank-level and robust for serial correlation and heteroschedasticity. Similar results are obtained when the regressions control for bank specific trends, these results are available from the author. 
Table 1: Macroprudential Capital Requirements in Europe

\begin{tabular}{|c|c|c|c|}
\hline Buffer & $\begin{array}{c}\text { CRD } \\
\text { Article }\end{array}$ & Level & Scope \\
\hline $\begin{array}{l}\text { Capital } \\
\text { conservation buffer } \\
\text { (CCoB) }\end{array}$ & Art. 129 & $\begin{array}{l}\text { The objective is to conserve the bank's capital. } \\
\text { Mandatory capital buffer equal to } 2.5 \% \text { of RWAs, this } \\
\text { implies a minimum CET1 ratio requirement is } 7 \%\end{array}$ & 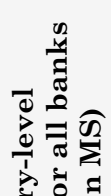 \\
\hline $\begin{array}{l}\text { Counter-cyclical } \\
\text { Capital buffer } \\
\text { (CCyB) }\end{array}$ & $\begin{array}{l}\text { Art. } 130, \\
135-140\end{array}$ & $\begin{array}{l}\text { The purpose of this buffer is to counteract the effects of } \\
\text { the economic cycle. Buffer rate calibrated on MS credit- } \\
\text { to-GDP gap. }\end{array}$ & 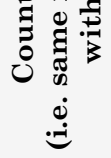 \\
\hline $\begin{array}{l}\text { G-SIB and O-SIB } \\
\text { Systemically } \\
\text { Important } \\
\text { Banks buffer (SIB) }\end{array}$ & Art. 131 & $\begin{array}{l}\text { For banks that are identified by the relevant authority } \\
\text { as systemically important: } \\
1 \leq \mathrm{x} \leq 3.5 \% \text { of RWAs for G-SII } \\
0 \leq \mathrm{x} \leq 2.0 \% \text { of RWAs for O-SII }\end{array}$ & 秀 \\
\hline $\begin{array}{l}\text { Systemic risk } \\
\text { buffer (SRB) }\end{array}$ & $\begin{array}{l}\text { Art. } 133 \\
\text { and } 134\end{array}$ & $\begin{array}{l}\text { To prevent and mitigate long term non-cyclical } \\
\text { systemic or macro-prudential risks: } \\
0 \leq \mathrm{x} \leq 5.0 \% \text { of RWA } \\
\text { Above } 5 \% \text { the MS must be authorized by Commission }\end{array}$ & 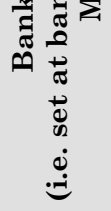 \\
\hline
\end{tabular}

Note: The table summarises the four macroprudential capital requirements introduced in EU in 2014 . The $\mathrm{CCoB}$ and the $\mathrm{CCyB}$ are country-level capital requirements levied on all banks within a country. The capital requirement for systemically important banks and the SRB buffer are applied at banklevel. MS stands for EU Member States, Norway, despite not being an EU Member State implemented the EU capital based macroprudential regulation. 
Table 2: Direction of Omitted Variable Bias

The table illustrates the sign of the bias due to omitted variable in a simple bivariate model where $x_{1}$ is the treatment variable and $x_{2}$ is the omitted variable:

\begin{tabular}{ccc}
$y=\beta_{1} x_{1}+\beta_{2} x_{2}+u$ \\
\hline \\
\hline $\operatorname{Corr}\left(x_{1}, x_{2}>0\right)$ & $\operatorname{Corr}\left(x_{1}, x_{2}<0\right)$ \\
\hline$\beta_{2}>0$ & Bias $>0$ & Bias $<0$ \\
$\beta_{2}<0$ & Bias $<0$ & Bias $>0$ \\
\hline
\end{tabular}


Table 3: Descriptive statistics by year: Capital, Requirements and Distance

The table summarize the evolution over time of the simple means (Panel A) and means conditional on treatment (Panel B) of the systemic macroprudential capital requirement (SMCR) imposed on banks. The SMCR consist of CET1 capital and is shown in the first row of each panel. Second rows present the overall CET1 capital requirement as the sum of the minimum CET1 capital requirement and the SMCR. Third rows show the average supply, i.e. the actual CET1 ratio in the sample of banks. Rows four show the distance from the OCR over the years, i.e. the average buffer the banks hold with respect to the CET1 capital requirement. The total capital ratio, including additional Tier1 instruments and Tier2 capital is reported in the last row of each panel. Standard deviations in parenthesis

\begin{tabular}{|c|c|c|c|c|c|c|c|c|}
\hline & 2010 & 2011 & 2012 & 2013 & 2014 & 2015 & 2016 & 2017 \\
\hline \multicolumn{9}{|l|}{ Panel A: Simple Means: } \\
\hline $\operatorname{SMCR}(\%)$ & $\begin{array}{c}0 \\
(0)\end{array}$ & $\begin{array}{c}0 \\
(0)\end{array}$ & $\begin{array}{c}0 \\
(0)\end{array}$ & $\begin{array}{c}0.014 \\
(0.170)\end{array}$ & $\begin{array}{c}0.149 \\
(0.618)\end{array}$ & $\begin{array}{c}0.442 \\
(1.032)\end{array}$ & $\begin{array}{c}0.656 \\
(1.070)\end{array}$ & $\begin{array}{c}0.870 \\
(1.100)\end{array}$ \\
\hline Overall CET1 Req. (OCR) (\%) & $\begin{array}{l}4.500 \\
(0)\end{array}$ & $\begin{array}{c}4.500 \\
(0)\end{array}$ & $\begin{array}{c}4.500 \\
(0)\end{array}$ & $\begin{array}{c}4.533 \\
(0.384)\end{array}$ & $\begin{array}{c}5.174 \\
(1.414)\end{array}$ & $\begin{array}{c}5.800 \\
(2.014)\end{array}$ & $\begin{array}{c}6.510 \\
(1.824)\end{array}$ & $\begin{array}{c}7.124 \\
(1.705)\end{array}$ \\
\hline CET1 Ratio(\%) & $\begin{array}{c}10.70 \\
(2.872)\end{array}$ & $\begin{array}{c}11.51 \\
(3.314)\end{array}$ & $\begin{array}{c}12.58 \\
(3.848)\end{array}$ & $\begin{array}{c}13.90 \\
(4.752)\end{array}$ & $\begin{array}{c}14.90 \\
(5.372)\end{array}$ & $\begin{array}{c}16.16 \\
(6.895)\end{array}$ & $\begin{array}{c}17.09 \\
(6.998)\end{array}$ & $\begin{array}{c}17.58 \\
(7.415)\end{array}$ \\
\hline Distance from OCR (\%) & $\begin{array}{c}7.190 \\
(6.295)\end{array}$ & $\begin{array}{c}8.043 \\
(6.536)\end{array}$ & $\begin{array}{c}8.523 \\
(6.432)\end{array}$ & $\begin{array}{c}9.806 \\
(6.935)\end{array}$ & $\begin{array}{c}9.993 \\
(6.192)\end{array}$ & $\begin{array}{c}10.33 \\
(6.622)\end{array}$ & $\begin{array}{c}10.50 \\
(6.620)\end{array}$ & $\begin{array}{c}10.47 \\
(7.270)\end{array}$ \\
\hline Tot. Capital Ratio(\%) & $\begin{array}{c}15.26 \\
(7.175)\end{array}$ & $\begin{array}{c}15.92 \\
(8.050)\end{array}$ & $\begin{array}{c}16.12 \\
(7.288)\end{array}$ & $\begin{array}{c}17.44 \\
(8.015)\end{array}$ & $\begin{array}{c}17.83 \\
(6.800)\end{array}$ & $\begin{array}{c}19.08 \\
(7.584)\end{array}$ & $\begin{array}{c}20.17 \\
(8.692)\end{array}$ & $\begin{array}{c}20.83 \\
(10.59)\end{array}$ \\
\hline Observations & 820 & 820 & 820 & 820 & 820 & 820 & 820 & 615 \\
\hline \multicolumn{9}{|c|}{ Panel B: Means Conditional on Treatment } \\
\hline $\operatorname{SMCR}(\%)$ & $\begin{array}{c}0 \\
(0)\end{array}$ & $\begin{array}{c}0 \\
(0)\end{array}$ & $\begin{array}{c}0 \\
(0)\end{array}$ & $\begin{array}{c}0.020 \\
(0.199)\end{array}$ & $\begin{array}{c}0.203 \\
(0.712)\end{array}$ & $\begin{array}{c}0.600 \\
(1.163)\end{array}$ & $\begin{array}{c}0.892 \\
(1.160)\end{array}$ & $\begin{array}{c}1.184 \\
(1.130)\end{array}$ \\
\hline Overall CET1 Cap. Req. (OCR) (\%) & $\begin{array}{c}4.500 \\
(0)\end{array}$ & $\begin{array}{c}4.500 \\
(0)\end{array}$ & $\begin{array}{c}4.500 \\
(0)\end{array}$ & $\begin{array}{c}4.545 \\
(0.447)\end{array}$ & $\begin{array}{c}5.349 \\
(1.564)\end{array}$ & $\begin{array}{c}6.067 \\
(2.203)\end{array}$ & $\begin{array}{c}6.849 \\
(1.967)\end{array}$ & $\begin{array}{c}7.509 \\
(1.809)\end{array}$ \\
\hline CET1 Ratio(\%) & $\begin{array}{c}11.36 \\
(2.858)\end{array}$ & $\begin{array}{c}11.93 \\
(2.921)\end{array}$ & $\begin{array}{c}12.81 \\
(3.278)\end{array}$ & $\begin{array}{c}14.16 \\
(4.179)\end{array}$ & $\begin{array}{c}15.07 \\
(5.327)\end{array}$ & $\begin{array}{c}16.39 \\
(7.264)\end{array}$ & $\begin{array}{c}17.15 \\
(7.301)\end{array}$ & $\begin{array}{c}17.63 \\
(7.029)\end{array}$ \\
\hline Distance from OCR (\%) & $\begin{array}{c}7.416 \\
(4.408)\end{array}$ & $\begin{array}{c}8.052 \\
(4.612)\end{array}$ & $\begin{array}{c}8.676 \\
(4.352)\end{array}$ & $\begin{array}{c}9.803 \\
(4.726)\end{array}$ & $\begin{array}{c}9.938 \\
(5.556)\end{array}$ & $\begin{array}{c}10.27 \\
(6.904)\end{array}$ & $\begin{array}{c}10.24 \\
(6.766)\end{array}$ & $\begin{array}{c}10.24 \\
(6.847)\end{array}$ \\
\hline Tot. Capital Ratio(\%) & $\begin{array}{c}15.50 \\
(5.077)\end{array}$ & $\begin{array}{c}15.96 \\
(5.508)\end{array}$ & $\begin{array}{c}16.21 \\
(4.972)\end{array}$ & $\begin{array}{c}17.26 \\
(5.149)\end{array}$ & $\begin{array}{c}17.80 \\
(5.761)\end{array}$ & $\begin{array}{c}19.15 \\
(7.609)\end{array}$ & $\begin{array}{c}20.08 \\
(8.090)\end{array}$ & $\begin{array}{c}20.76 \\
(7.988)\end{array}$ \\
\hline Observations & 604 & 604 & 604 & 604 & 604 & 604 & 604 & 453 \\
\hline
\end{tabular}


Table 4: Descriptive statistics: EU G-SIB and O-SIB Financial Accounts

The table summarizes descriptive statistics of the balance sheet variables used in the paper. The sample is the sample of designated Systemically Important Banks (SIB) in the EU as described in section 4.1. For each variable the simple mean, standard deviation, the median, the 25th and 75th quintiles and the maximum are shown. Time period: 2006Q1-2017Q3. The data source is SNL Financials.

\begin{tabular}{|c|c|c|c|c|c|c|}
\hline & Mean & Std.dev. & $\mathrm{p} 25$ & $\mathrm{p} 50$ & p75 & Max. \\
\hline \multicolumn{7}{|l|}{ Capital Position: } \\
\hline CET1 Ratio(\%) & 13.64 & 6.06 & 10.20 & 12.60 & 15.70 & 74.93 \\
\hline Distance from OCR (\%) & 8.34 & 6.56 & 4.84 & 7.29 & 10.14 & 82.36 \\
\hline Tot. Capital Ratio(\%) & 16.58 & 7.87 & 12.28 & 15.00 & 18.30 & 111.64 \\
\hline Leverage Ratio (\%) & 7.60 & 4.07 & 4.66 & 6.86 & 9.80 & 32.98 \\
\hline \multicolumn{7}{|l|}{ Risk: } \\
\hline RWA (bln.) & 70.37 & 139.15 & 5.54 & 19.26 & 60.89 & 1129.63 \\
\hline RWA/Assets(\%) & 50.06 & 21.41 & 33.14 & 50.29 & 64.91 & 261.02 \\
\hline \multicolumn{7}{|l|}{ Assets: } \\
\hline Tot. Assets (bln.) & 196.15 & 379.97 & 8.58 & 39.19 & 198.37 & 2506.28 \\
\hline Gross Loans/Assets(\%) & 58.29 & 19.62 & 48.08 & 62.57 & 71.59 & 121.83 \\
\hline Net Loans/Assets (\%) & 54.71 & 19.06 & 44.77 & 59.03 & 67.53 & 105.21 \\
\hline Securities Holdings/Assets (\%) & 25.13 & 16.92 & 13.86 & 22.15 & 32.22 & 99.56 \\
\hline Total Cash/Assets(\%) & 15.29 & 11.86 & 6.94 & 12.23 & 20.58 & 93.64 \\
\hline \multicolumn{7}{|l|}{ Securities Holdings: } \\
\hline Securities Held for trading/Assets (\%) & 7.55 & 9.50 & 1.17 & 4.15 & 10.08 & 65.40 \\
\hline Securities Available for Sale/Assets (\%) & 9.34 & 8.29 & 2.59 & 8.13 & 13.88 & 57.99 \\
\hline Securities Held to Maturity/Assets (\%) & 2.68 & 5.63 & 0.00 & 0.24 & 2.51 & 89.18 \\
\hline \multicolumn{7}{|l|}{ Funding Structure: } \\
\hline Deposits/Assets (\%) & 48.45 & 22.96 & 31.46 & 51.25 & 66.51 & 98.31 \\
\hline Total Wholesale Funding/Assets(\%) & 33.23 & 21.95 & 16.69 & 29.29 & 45.48 & 95.82 \\
\hline Debt/Assets (\%) & 17.92 & 18.13 & 4.62 & 13.08 & 24.69 & 95.82 \\
\hline \multicolumn{7}{|l|}{ Interconnectedness: } \\
\hline Loans to Banks/Assets (\%) & 10.01 & 11.23 & 3.07 & 6.21 & 12.95 & 92.65 \\
\hline Tot. HFT Assets/Assets (\%) & 8.34 & 10.63 & 1.23 & 4.22 & 11.40 & 67.32 \\
\hline Securities OTC derivatives/Assets (\%) & 5.56 & 10.01 & 0.37 & 1.84 & 6.12 & 74.30 \\
\hline Total cash balance at C.B./Assets (\%) & 5.34 & 6.08 & 1.13 & 3.09 & 7.19 & 43.88 \\
\hline \multicolumn{7}{|l|}{ Profitability: } \\
\hline $\mathrm{ROA}(\%)$ & 0.32 & 1.14 & 0.10 & 0.31 & 0.71 & 6.56 \\
\hline Cost/Income $(\%)$ & 58.64 & 21.87 & 47.83 & 56.14 & 65.60 & 390.50 \\
\hline
\end{tabular}




\section{Table 5: The Impact on Capital}

The table summarises the baseline reduced form specification of the change in systemic macroprudential capital requirements (SMCR) on bank capital in Columns (1)-(3). Columns (4)-(6) present the heterogenous impact by bank distance from the overall CET1 capital requirements (OCR). All dependent variables that are measured in levels, i.e. CET1 capital in columns (2) and (5) and total capital in columns (3) and (6), are transformed using natural logarithms. Bank-level control variables are as specified in equation 1. Time period: 2010Q1-2017Q3. Standard errors are shown in parenthesis clustered at bank-level, robust to heteroscedasticity and serial correlation. FE stands for fixed-effects. Stars indicate statistical significance levels: ${ }^{* * *} \mathrm{p}<0.01,{ }^{* *} \mathrm{p}<0.05,{ }^{*} \mathrm{p}<0.10$.

\begin{tabular}{|c|c|c|c|c|c|c|}
\hline & \multicolumn{3}{|c|}{ Non-Binding } & \multicolumn{3}{|c|}{ Binding } \\
\hline & $\begin{array}{l}\text { (1) } \\
\text { CET1 Ratio } \\
\text { (p.p.) }\end{array}$ & $\begin{array}{l}(2) \\
\text { CET1 } \\
(\ln )\end{array}$ & $\begin{array}{l}\text { Tot. Capital } \\
\quad(\ln )\end{array}$ & $\begin{array}{l}\text { (4) } \\
\text { CET1 Ratio } \\
\text { (p.p.) }\end{array}$ & $\begin{array}{l}(5) \\
\text { CET1 } \\
(\ln )\end{array}$ & $\begin{array}{l}\text { (6) } \\
\text { Tot. Capital } \\
\text { (ln) }\end{array}$ \\
\hline SMCR & $\begin{array}{l}-0.054 \\
(0.359)\end{array}$ & $\begin{array}{c}0.089 \\
(0.027)^{* * *}\end{array}$ & $\begin{array}{c}0.081 \\
(0.027)^{* * *}\end{array}$ & $\begin{array}{c}0.834 \\
(0.402)^{* *}\end{array}$ & $\begin{array}{c}0.177 \\
(0.036)^{* * *}\end{array}$ & $\begin{array}{c}0.116 \\
(0.042)^{* * *}\end{array}$ \\
\hline $\begin{array}{l}\mathrm{SMCR} \times \\
2 \mathrm{pp}<\text { OCR distance }<5 \mathrm{pp}\end{array}$ & & & & $\begin{array}{l}-0.143 \\
(0.215)\end{array}$ & $\begin{array}{c}-0.042 \\
(0.022)^{*}\end{array}$ & $\begin{array}{l}-0.003 \\
(0.026)\end{array}$ \\
\hline $\begin{array}{l}\mathrm{SMCR} \times \\
5 \mathrm{pp}<\text { OCR distance }<10 \mathrm{pp}\end{array}$ & & & & $\begin{array}{c}0.003 \\
(0.214)\end{array}$ & $\begin{array}{l}-0.047 \\
(0.024)^{*}\end{array}$ & $\begin{array}{l}-0.012 \\
(0.031)\end{array}$ \\
\hline $\begin{array}{l}\text { SMCR } \times \\
\text { OCR distance }>10 p p\end{array}$ & & & & $\begin{array}{c}0.087 \\
(0.232)\end{array}$ & $\begin{array}{c}-0.053 \\
(0.024)^{* *}\end{array}$ & $\begin{array}{l}-0.013 \\
(0.031)\end{array}$ \\
\hline $\begin{array}{l}\text { Bank Controls } \\
\text { Bank FE } \\
\text { Country-quarter FE }\end{array}$ & $\begin{array}{l}\text { yes } \\
\text { yes } \\
\text { yes }\end{array}$ & $\begin{array}{l}\text { yes } \\
\text { yes } \\
\text { yes }\end{array}$ & $\begin{array}{l}\text { yes } \\
\text { yes } \\
\text { yes }\end{array}$ & $\begin{array}{l}\text { yes } \\
\text { yes } \\
\text { yes }\end{array}$ & $\begin{array}{l}\text { yes } \\
\text { yes } \\
\text { yes }\end{array}$ & $\begin{array}{l}\text { yes } \\
\text { yes } \\
\text { yes }\end{array}$ \\
\hline $\begin{array}{l}\text { Obs. } \\
\text { N. clusters } \\
\text { R2 }\end{array}$ & $\begin{array}{c}3174 \\
137 \\
0.688\end{array}$ & $\begin{array}{c}3174 \\
137 \\
0.672\end{array}$ & $\begin{array}{l}3174 \\
137 \\
0.663\end{array}$ & $\begin{array}{l}3173 \\
137 \\
0.800\end{array}$ & $\begin{array}{l}3173 \\
137 \\
0.763\end{array}$ & $\begin{array}{l}3173 \\
137 \\
0.695\end{array}$ \\
\hline
\end{tabular}


Table 6: The Impact on Risk

The table illustrates the baseline reduced form specification of the change in systemic macroprudential capital requirements (SMCR) on banks' risk-taking and assets in Columns (1)-(3). Columns (4)-(6) show the heterogenous impact by bank distance from the overall CET1 capital requirements (OCR). All dependent variables that are measured in levels, i.e. CET1 capital in column (2) and Risk-weighted Assets in column (3), are transformed using natural logarithms. Bank-level control variables are as specified in equation 1. Time period: 2010Q1-2017Q3. Standard errors are shown in parenthesis clustered at bank-level, robust to heteroscedasticity and serial correlation. FE stands for fixed-effects. Stars indicate statistical significance levels: ${ }^{* * *} \mathrm{p}<0.01,{ }^{* *} \mathrm{p}<0.05,{ }^{*} \mathrm{p}<0.10$.

\begin{tabular}{|c|c|c|c|c|c|c|}
\hline & \multicolumn{3}{|c|}{ Non-Binding } & \multicolumn{3}{|c|}{ Binding } \\
\hline & $\begin{array}{c}(1) \\
\text { RWA } \\
(\ln )\end{array}$ & $\begin{array}{c}\text { (2) } \\
\text { RWA/Assets } \\
\text { (p.p.) }\end{array}$ & $\begin{array}{c}(3) \\
\text { Tot. Assets } \\
(\ln )\end{array}$ & $\begin{array}{c}(4) \\
\text { RWA } \\
(\ln )\end{array}$ & $\begin{array}{c}\text { (5) } \\
\text { RWA/Assets } \\
\text { (p.p.) }\end{array}$ & $\begin{array}{c}\begin{array}{l}(6) \\
\text { Tot. Assets } \\
(\ln )\end{array} \\
\end{array}$ \\
\hline SMCR & $\begin{array}{c}0.101 \\
(0.023)^{* * *}\end{array}$ & $\begin{array}{c}6.873 \\
(1.388)^{* * *}\end{array}$ & $\begin{array}{l}-0.007 \\
(0.008)\end{array}$ & $\begin{array}{c}0.065 \\
(0.026)^{* *}\end{array}$ & $\begin{array}{c}6.073 \\
(1.455)^{* * *}\end{array}$ & $\begin{array}{l}-0.016 \\
(0.012)\end{array}$ \\
\hline $\begin{array}{l}\mathrm{SMCR} \times \\
2 \mathrm{pp}<\mathrm{OCR} \text { distance }<5 \mathrm{pp}\end{array}$ & & & & $\begin{array}{c}0.002 \\
(0.009)\end{array}$ & $\begin{array}{l}-0.139 \\
(0.419)\end{array}$ & $\begin{array}{l}-0.002 \\
(0.006)\end{array}$ \\
\hline $\begin{array}{l}\mathrm{SMCR} \times \\
5 \mathrm{pp}<\mathrm{OCR} \text { distance }<10 \mathrm{pp}\end{array}$ & & & & $\begin{array}{c}0.011 \\
(0.011)\end{array}$ & $\begin{array}{l}-0.219 \\
(0.533)\end{array}$ & $\begin{array}{c}0.005 \\
(0.005)\end{array}$ \\
\hline $\begin{array}{l}\text { SMCR } \times \\
\text { OCR distance }>10 \mathrm{pp}\end{array}$ & & & & $\begin{array}{c}0.013 \\
(0.011)\end{array}$ & $\begin{array}{c}0.242 \\
(0.523)\end{array}$ & $\begin{array}{c}0.004 \\
(0.005)\end{array}$ \\
\hline $\begin{array}{l}\text { Bank Controls } \\
\text { Bank FE } \\
\text { Country-quarter FE }\end{array}$ & $\begin{array}{l}\text { yes } \\
\text { yes } \\
\text { yes }\end{array}$ & $\begin{array}{l}\text { yes } \\
\text { yes } \\
\text { yes }\end{array}$ & $\begin{array}{l}\text { yes } \\
\text { yes } \\
\text { yes }\end{array}$ & $\begin{array}{l}\text { yes } \\
\text { yes } \\
\text { yes }\end{array}$ & $\begin{array}{l}\text { yes } \\
\text { yes } \\
\text { yes }\end{array}$ & $\begin{array}{l}\text { yes } \\
\text { yes } \\
\text { yes }\end{array}$ \\
\hline $\begin{array}{l}\text { Obs. } \\
\text { N. clusters } \\
\text { R2 }\end{array}$ & $\begin{array}{c}3277 \\
137 \\
0.749\end{array}$ & $\begin{array}{c}3277 \\
137 \\
0.646\end{array}$ & $\begin{array}{l}3277 \\
137 \\
0.875\end{array}$ & $\begin{array}{c}3195 \\
137 \\
0.768\end{array}$ & $\begin{array}{l}3195 \\
137 \\
0.677\end{array}$ & $\begin{array}{l}3195 \\
137 \\
0.875\end{array}$ \\
\hline
\end{tabular}


Table 7: The Impact on Capital: the role of bank size and internal rating approach (IRB)

The table summarises the reduced form specification of the change in systemic macroprudential capital requirements (SMCR) on bank capital. Columns (1)-(3) present the heterogenous impact by bank size and distance from the overall CET1 capital requirements (OCR). Columns (4)-(6) show the heterogeneous impact by IRB and distance from the OCR. Bank-level control variables are as specified in equation 1. Time period: 2010Q1-2017Q3. Standard errors are shown in parenthesis clustered at bank-level, robust to heteroscedasticity and serial correlation. FE stands for fixed-effects. Stars indicate statistical significance levels: ${ }^{* * *} \mathrm{p}<0.01,{ }^{* *} \mathrm{p}<0.05,{ }^{*} \mathrm{p}<0.10$.

\begin{tabular}{|c|c|c|c|c|c|c|}
\hline & \multicolumn{3}{|c|}{ Size } & \multicolumn{3}{|c|}{ IRB } \\
\hline & $\begin{array}{l}\text { (1) } \\
\text { CET1 Ratio } \\
\text { (p.p.) }\end{array}$ & $\begin{array}{l}(2) \\
\text { CET1 } \\
(\ln )\end{array}$ & $\begin{array}{l}\text { Tot. } \stackrel{(3)}{\text { Capital }} \\
(\ln )\end{array}$ & $\begin{array}{l}\text { (4) } \\
\text { CET1 Ratio } \\
\text { (p.p.) }\end{array}$ & $\begin{array}{l}(5) \\
\text { CET1 } \\
(\ln )\end{array}$ & $\begin{array}{l}\text { (6) } \\
\text { Tot. Capital } \\
\text { (ln) }\end{array}$ \\
\hline SMCR & $\begin{array}{c}0.214 \\
(0.680)\end{array}$ & $\begin{array}{c}0.133 \\
(0.049)^{* * *}\end{array}$ & $\begin{array}{c}0.057 \\
(0.056)\end{array}$ & $\begin{array}{l}-0.006 \\
(0.543)\end{array}$ & $\begin{array}{c}0.149 \\
(0.046)^{* * *}\end{array}$ & $\begin{array}{c}0.099 \\
(0.049)^{* *}\end{array}$ \\
\hline $\mathrm{SMCR} \times$ & & & & & & \\
\hline OCR distance > 2pp & $\begin{array}{c}0.131 \\
(0.463)\end{array}$ & $\begin{array}{l}-0.027 \\
(0.024)\end{array}$ & $\begin{array}{l}-0.006 \\
(0.031)\end{array}$ & $\begin{array}{c}0.164 \\
(0.503)\end{array}$ & $\begin{array}{l}-0.049 \\
(0.035)\end{array}$ & $\begin{array}{l}-0.025 \\
(0.038)\end{array}$ \\
\hline $\begin{array}{l}\text { SMCR } \times \\
\text { 20bln. }<\text { Tot.Ass }<100 \text { bln }\end{array}$ & $\begin{array}{c}0.701 \\
(3.232)\end{array}$ & $\begin{array}{c}0.458 \\
(0.503)\end{array}$ & $\begin{array}{c}0.013 \\
(0.420)\end{array}$ & & & \\
\hline $\begin{array}{l}\text { SMCR } \times \\
\text { Tot.Ass }>100 \text { bln. }\end{array}$ & $\begin{array}{c}-0.506 \\
(0.655)\end{array}$ & $\begin{array}{c}-0.043 \\
(0.062)\end{array}$ & $\begin{array}{c}-0.055 \\
(0.070)\end{array}$ & & & \\
\hline $\begin{array}{l}\text { SMCR } \times \\
\text { OCR distance }>2 \text { pp } \times\end{array}$ & & & & & & \\
\hline 20bln. $<$ Tot.Ass $<100$ bln & $\begin{array}{l}-0.683 \\
(3.213)\end{array}$ & $\begin{array}{l}-0.455 \\
(0.504)\end{array}$ & $\begin{array}{c}0.006 \\
(0.421)\end{array}$ & & & \\
\hline $\begin{array}{l}\text { SMCR } \times \\
\text { OCR distance }>2 \text { pp } \times\end{array}$ & & & & & & \\
\hline Tot.Ass > 100bln. & $\begin{array}{l}-0.300 \\
(0.622)\end{array}$ & $\begin{array}{c}0.011 \\
(0.056)\end{array}$ & $\begin{array}{c}0.065 \\
(0.068)\end{array}$ & & & \\
\hline $\mathrm{SMCR} \times I R B$ & & & & $\begin{array}{l}-0.229 \\
(0.495)\end{array}$ & $\begin{array}{l}-0.075 \\
(0.056)\end{array}$ & $\begin{array}{l}-0.100 \\
(0.069)\end{array}$ \\
\hline $\begin{array}{l}\text { SMCR } \times \\
\text { OCR distance }>2 \mathrm{pp} \times I R B\end{array}$ & & & & $\begin{array}{c}0.051 \\
(0.555)\end{array}$ & $\begin{array}{c}0.065 \\
(0.056)\end{array}$ & $\begin{array}{c}0.097 \\
(0.070)\end{array}$ \\
\hline Bank Controls & yes & yes & yes & yes & yes & yes \\
\hline Bank FE & yes & yes & yes & yes & yes & yes \\
\hline Country-quarter FE & yes & yes & yes & yes & yes & yes \\
\hline Obs. & 3312 & 3312 & 3312 & 3298 & 3298 & 3298 \\
\hline N. clusters & 144 & 144 & 144 & 143 & 143 & 143 \\
\hline $\mathrm{R} 2$ & 0.692 & 0.711 & 0.662 & 0.696 & 0.706 & 0.656 \\
\hline
\end{tabular}


Table 8: The Impact on Risk: the role of bank size and internal rating approach (IRB)

The table illustrates the estimates of a reduced form specification for the impact of the change in systemic macroprudential capital requirements (SMCR) on banks' risk-taking and assets. Columns (1)-(3) show the heterogenous impact by bank size. Columns (4)-(6) show the heterogenous impact by bank size and IRB. Variables measured in levels, i.e. risk-weighted Assets and total assets, are transformed using natural logarithms. Bank-level control variables are as specified in equation 1. Time period: 2010Q1-2017Q3. Standard errors are shown in parenthesis clustered at bank-level, robust to heteroscedasticity and serial correlation. FE stands for fixed-effects. Stars indicate statistical significance levels: $* * * \mathrm{p}<0.01,{ }^{* *} \mathrm{p}<0.05,{ }^{*} \mathrm{p}<0.10$.

\begin{tabular}{|c|c|c|c|c|c|c|}
\hline & \multicolumn{3}{|c|}{ Size } & \multicolumn{3}{|c|}{ Size and IRB Banks } \\
\hline & $\begin{array}{l}(1) \\
\text { RWA } \\
(\ln )\end{array}$ & $\begin{array}{c}(2) \\
\text { RWA/Assets } \\
\text { (p.p.) }\end{array}$ & $\begin{array}{l}(3) \\
\text { Tot.Assets } \\
\quad(\ln ) \\
\end{array}$ & $\begin{array}{l}(4) \\
\text { RWA } \\
(\ln )\end{array}$ & $\begin{array}{c}(5) \\
\text { RWA/Assets } \\
\text { (p.p) }\end{array}$ & $\begin{array}{c}(6) \\
\text { Tot.Assets } \\
\quad(\ln ) \\
\end{array}$ \\
\hline SMCR & $\begin{array}{c}0.071 \\
(0.036)^{*}\end{array}$ & $\begin{array}{c}3.944 \\
(1.731)^{* *}\end{array}$ & $\begin{array}{l}-0.004 \\
(0.018)\end{array}$ & $\begin{array}{l}0.066 \\
(0.043)\end{array}$ & $\begin{array}{c}4.345 \\
(1.904)^{* *}\end{array}$ & $\begin{array}{l}-0.020 \\
(0.019)\end{array}$ \\
\hline $\begin{array}{l}\text { SMCR } \times \\
\text { 20bln. }<\text { Tot.Ass }<100 \text { bln. }\end{array}$ & $\begin{array}{c}0.020 \\
(0.019)\end{array}$ & $\begin{array}{c}1.864 \\
(1.073)^{*}\end{array}$ & $\begin{array}{l}-0.002 \\
(0.010)\end{array}$ & $\begin{array}{c}0.030 \\
(0.024)\end{array}$ & $\begin{array}{c}2.963 \\
(1.224)^{* *}\end{array}$ & $\begin{array}{l}-0.006 \\
(0.010)\end{array}$ \\
\hline $\begin{array}{l}\text { SMCR } \times \\
\text { Tot.Ass }>100 \text { bln. }\end{array}$ & $\begin{array}{c}0.022 \\
(0.024)\end{array}$ & $\begin{array}{c}2.079 \\
(1.149)^{*}\end{array}$ & $\begin{array}{l}-0.001 \\
(0.011)\end{array}$ & $\begin{array}{c}0.181 \\
(0.049)^{* * *}\end{array}$ & $\begin{array}{c}5.324 \\
(2.149)^{* *}\end{array}$ & $\begin{array}{c}0.004 \\
(0.018)\end{array}$ \\
\hline $\mathrm{SMCR} \times I R B$ & & & & $\begin{array}{c}0.001 \\
(0.014)\end{array}$ & $\begin{array}{l}-0.034 \\
(0.901)\end{array}$ & $\begin{array}{c}0.008 \\
(0.004)^{*}\end{array}$ \\
\hline $\begin{array}{l}\text { SMCR } \times I R B \times \\
\text { 20bln. }<\text { Tot.Ass }<100 \text { bln. }\end{array}$ & & & & $\begin{array}{l}-0.009 \\
(0.031)\end{array}$ & $\begin{array}{l}-1.498 \\
(1.469)\end{array}$ & $\begin{array}{c}0.008 \\
(0.010)\end{array}$ \\
\hline $\begin{array}{l}\text { SMCR } \times I R B \times \\
\text { Tot.Ass }>100 \text { bln. }\end{array}$ & & & & $\begin{array}{c}-0.157 \\
(0.042)^{* * *}\end{array}$ & $\begin{array}{c}-3.595 \\
(1.802)^{* *}\end{array}$ & $\begin{array}{l}-0.002 \\
(0.016)\end{array}$ \\
\hline $\begin{array}{l}\text { Bank Controls } \\
\text { Bank FE } \\
\text { Country-quarter FE }\end{array}$ & $\begin{array}{l}\text { yes } \\
\text { yes } \\
\text { yes }\end{array}$ & $\begin{array}{l}\text { yes } \\
\text { yes } \\
\text { yes }\end{array}$ & $\begin{array}{l}\text { yes } \\
\text { yes } \\
\text { yes }\end{array}$ & $\begin{array}{l}\text { yes } \\
\text { yes } \\
\text { yes }\end{array}$ & $\begin{array}{l}\text { yes } \\
\text { yes } \\
\text { yes }\end{array}$ & $\begin{array}{l}\text { yes } \\
\text { yes } \\
\text { yes }\end{array}$ \\
\hline $\begin{array}{l}\text { Obs. } \\
\text { N. clusters } \\
\text { R2 }\end{array}$ & $\begin{array}{c}3277 \\
137 \\
0.750\end{array}$ & $\begin{array}{c}3277 \\
137 \\
0.648\end{array}$ & $\begin{array}{c}3277 \\
137 \\
0.878\end{array}$ & $\begin{array}{c}3277 \\
137 \\
0.756\end{array}$ & $\begin{array}{c}3277 \\
137 \\
0.655\end{array}$ & $\begin{array}{c}3277 \\
137 \\
0.878\end{array}$ \\
\hline
\end{tabular}


Table 9: Profitability, Funding and Leverage

The table illustrates the reduced form specification for the impact of the change in systemic macroprudential capital requirements (SMCR) on banks' risk-taking. Columns (1)-(2) show the heterogenous impact by bank profitability as measured with a dummy equal to one if the bank has above the sample median net interest income (NII). Columns (3)-(4) show the heterogenous impact by wholesale funding (WSF) as captured by a dummy equal to one for above median WSF. Columns (5)-(6) illustrate the impact by bank leverage as measured by a dummy above median for the ratio of Tier1 capital on total assets (LR). Bank-level control variables are as specified in equation 1. Time period: 2010Q1-2017Q3. Standard errors are shown in parenthesis clustered at bank-level, robust to heteroscedasticity and serial correlation. FE stands for fixed-effects. Stars indicate statistical significance levels: $* * * p<0.01$, $* * \mathrm{p}<0.05,{ }^{*} \mathrm{p}<0.10$.

\begin{tabular}{|c|c|c|c|c|c|c|}
\hline & \multicolumn{2}{|c|}{ NII } & \multicolumn{2}{|c|}{ Wholesale Funding } & \multicolumn{2}{|c|}{ Leverage Ratio } \\
\hline & $\begin{array}{c}(1) \\
\text { RWA } \\
(\ln )\end{array}$ & $\begin{array}{c}\text { (2) } \\
\text { RWA/Assets } \\
\text { (p.p.) }\end{array}$ & $\begin{array}{c}(3) \\
\text { RWA } \\
(\ln ) \\
\end{array}$ & $\begin{array}{c}(4) \\
\text { RWA/Assets } \\
\text { (p.p.) }\end{array}$ & $\begin{array}{c}(5) \\
\text { RWA } \\
(\ln ) \\
\end{array}$ & $\begin{array}{c}\text { (6) } \\
\text { RWA/Assets } \\
\text { (p.p.) }\end{array}$ \\
\hline SMCR & $\begin{array}{c}0.070 \\
(0.029)^{* *}\end{array}$ & $\begin{array}{c}4.296 \\
(1.262)^{* * *}\end{array}$ & $\begin{array}{c}0.066 \\
(0.032)^{* *}\end{array}$ & $\begin{array}{c}3.699 \\
(1.341)^{* * *}\end{array}$ & $\begin{array}{c}0.052 \\
(0.032)\end{array}$ & $\begin{array}{c}3.943 \\
(1.389)^{* * *}\end{array}$ \\
\hline $\begin{array}{l}\text { SMCR } \times \\
>20 \text { bln. }<\text { Tot.Ass }<100 \text { bln. }\end{array}$ & $\begin{array}{c}0.026 \\
(0.017)\end{array}$ & $\begin{array}{c}2.158 \\
(0.815)^{* * *}\end{array}$ & $\begin{array}{c}0.022 \\
(0.018)\end{array}$ & $\begin{array}{c}2.101 \\
(0.897)^{* *}\end{array}$ & $\begin{array}{c}0.030 \\
(0.024)\end{array}$ & $\begin{array}{c}2.199 \\
(1.226)^{*}\end{array}$ \\
\hline $\begin{array}{l}\text { SMCR } \times \\
\text { Tot.Ass }>100 \text { bln. }\end{array}$ & $\begin{array}{c}0.055 \\
(0.025)^{* *}\end{array}$ & $\begin{array}{c}2.842 \\
(0.993)^{* * *}\end{array}$ & $\begin{array}{c}0.027 \\
(0.027)\end{array}$ & $\begin{array}{c}2.310 \\
(1.104)^{* *}\end{array}$ & $\begin{array}{c}0.033 \\
(0.026)\end{array}$ & $\begin{array}{c}2.605 \\
(1.141)^{* *}\end{array}$ \\
\hline $\mathrm{SMCR} \times N I I$ & $\begin{array}{c}0.018 \\
(0.013)\end{array}$ & $\begin{array}{c}1.142 \\
(0.741)\end{array}$ & & & & \\
\hline $\mathrm{SMCR} \times N I I \times$ & -0.029 & -1.634 & & & & \\
\hline$>$ 20bln. $<$ Tot.Ass < 100bln. & $(0.013)^{* *}$ & $(0.761)^{* *}$ & & & & \\
\hline $\mathrm{SMCR} \times N I I \times$ & -0.055 & -2.067 & & & & \\
\hline Tot.Ass > 100bln. & $(0.020)^{* * *}$ & $(0.925)^{* *}$ & & & & \\
\hline $\mathrm{SMCR} \times W S F$ & & & $\begin{array}{c}0.011 \\
(0.011)\end{array}$ & $\begin{array}{c}1.339 \\
(0.633)^{* *}\end{array}$ & & \\
\hline SMCR $\times W S F \times$ & & & -0.059 & -2.124 & & \\
\hline$>$ 20bln. $<$ Tot.Ass $<100$ bln & & & $(0.025)^{* *}$ & $(1.132)^{*}$ & & \\
\hline SMCR $\times W S F \times$ & & & -0.060 & -2.110 & & \\
\hline Tot.Ass > 100bln. & & & $(0.025)^{* *}$ & $(0.994)^{* *}$ & & \\
\hline $\mathrm{SMCR} \times L R$ & & & & & $\begin{array}{c}0.026 \\
(0.027)\end{array}$ & $\begin{array}{l}0.456 \\
(1.328)\end{array}$ \\
\hline $\mathrm{SMCR} \times L R \times$ & & & & & -0.014 & -0.451 \\
\hline$>$ 20bln. $<$ Tot.Ass < 100bln. & & & & & $(0.027)$ & $(1.355)$ \\
\hline $\mathrm{SMCR} \times L R \times$ & & & & & -0.021 & -1.010 \\
\hline$>$ 20bln. $<$ Tot.Ass $<100$ bln & & & & & $(0.027)$ & $(1.396)$ \\
\hline Bank Controls & yes & yes & yes & yes & yes & yes \\
\hline Bank FE & yes & yes & yes & yes & yes & yes \\
\hline Country-quarter FE & yes & yes & yes & yes & yes & yes \\
\hline Obs. & 2794 & 2794 & 2713 & 2713 & 2794 & 2794 \\
\hline N. clusters & 142 & 142 & 142 & 142 & 142 & 142 \\
\hline $\mathrm{R} 2$ & 0.747 & 0.644 & 0.747 & 0.649 & 0.748 & 0.644 \\
\hline
\end{tabular}


Table 10: Bank Trends

The table presents the reduced form specification augmented with bank specific trends to control for the presence of diverging trend across banks. SMCR stands for systemic macroprudential capital requirement. Columns (1)-(3) present the estimates for the impact on capital differentiated by the distance from the OCR. Columns (4)-(5) show the evidence for risk and assets without differentiating by distance from OCR since risk and capital are not sensitive to distance from OCR, see 6. Bank-level control variables are as specified in equation 1. Time period: 2010Q1-2017Q3. Standard errors are shown in parenthesis clustered at bank-level, robust to heteroscedasticity and serial correlation. FE stands for fixed-effects. Stars indicate statistical significance levels: ${ }^{* * *} \mathrm{p}<0.01,{ }^{* *} \mathrm{p}<0.05,{ }^{*} \mathrm{p}<0.10$.

\begin{tabular}{|c|c|c|c|c|c|c|}
\hline & \multicolumn{3}{|c|}{ Capital } & \multicolumn{3}{|c|}{ Risk } \\
\hline & $\begin{array}{c}(1) \\
\text { CET1 Ratio } \\
\text { (p.p.) }\end{array}$ & $\begin{array}{c}(2) \\
\text { CET1 } \\
(\ln ) \\
\end{array}$ & $\begin{array}{c}(3) \\
\text { Tot. Capital } \\
(\ln ) \\
\end{array}$ & $\begin{array}{c}(4) \\
\text { RWA } \\
(\ln ) \\
\end{array}$ & $\begin{array}{c}(5) \\
\text { RWA/Assets } \\
\text { (p.p.) }\end{array}$ & $\begin{array}{c}\text { (6) } \\
\text { Tot. Assets } \\
\quad(\ln ) \\
\end{array}$ \\
\hline SMCR & $\begin{array}{l}-0.265 \\
(0.371)\end{array}$ & $\begin{array}{c}0.064 \\
(0.037)^{*}\end{array}$ & $\begin{array}{c}0.074 \\
(0.028)^{* * *}\end{array}$ & $\begin{array}{c}0.061 \\
(0.029)^{* *}\end{array}$ & $\begin{array}{c}3.115 \\
(1.555)^{* *}\end{array}$ & $\begin{array}{l}-0.008 \\
(0.012)\end{array}$ \\
\hline Bank Controls & yes & yes & yes & yes & yes & yes \\
\hline Bank FE & yes & yes & yes & yes & yes & yes \\
\hline Country-quarter FE & yes & yes & yes & yes & yes & yes \\
\hline Bank Trends & yes & yes & yes & yes & yes & yes \\
\hline Obs. & 3312 & 3312 & 3312 & 3312 & 3312 & 3312 \\
\hline N. clusters & 144 & 144 & 144 & 144 & 144 & 144 \\
\hline $\mathrm{R} 2$ & 0.804 & 0.778 & 0.791 & 0.845 & 0.824 & 0.898 \\
\hline
\end{tabular}




\section{Table 11: Anticipation Effects}

The table shows the impact of the change in systemic macroprudential capital requirements (SMCR) on bank capital, it includes two years leads of the impact to assess the presence of anticipation effects. Columns (1)-(3) present the impact on capital variables while Columns (4)-(6) present the estimates for the RWA and its components. Bank-level control variables are as specified in equation 4. Time period: 2010Q1-2017Q3. Standard errors are shown in parenthesis clustered at bank-level, and robust to heteroscedasticity and serial correlation. FE stands for fixed-effects. Stars indicate statistical significance levels: $* * * \mathrm{p}<0.01,{ }^{* *} \mathrm{p}<0.05,{ }^{*} \mathrm{p}<0.10$.

\begin{tabular}{|c|c|c|c|c|c|c|}
\hline & \multicolumn{3}{|c|}{ Capital } & \multicolumn{3}{|c|}{ Risk } \\
\hline & $\begin{array}{c}\text { (1) } \\
\text { CET1 Ratio } \\
\text { (p.p.) }\end{array}$ & $\begin{array}{c}(2) \\
\text { CET1 } \\
(\ln ) \\
\end{array}$ & $\begin{array}{c}(3) \\
\text { Tot. Capital } \\
(\ln ) \\
\end{array}$ & $\begin{array}{l}(4) \\
\text { RWA } \\
(\ln ) \\
\end{array}$ & $\begin{array}{c}(5) \\
\text { RWA/Assets } \\
\text { (p.p.) }\end{array}$ & $\begin{array}{l}\text { (6) } \\
\text { Tot. Assets } \\
\quad(\ln )\end{array}$ \\
\hline SMCR & $\begin{array}{c}0.132 \\
(0.168)\end{array}$ & $\begin{array}{c}0.107 \\
(0.028)^{* * *}\end{array}$ & $\begin{array}{c}0.072 \\
(0.017)^{* * *}\end{array}$ & $\begin{array}{c}0.107 \\
(0.028)^{* * *}\end{array}$ & $\begin{array}{c}7.009 \\
(2.608)^{* * *}\end{array}$ & $\begin{array}{c}0.014 \\
(0.017)\end{array}$ \\
\hline $\mathrm{SMCR}_{t+1 \text { year }}$ & $\begin{array}{c}1.084 \\
(0.302)^{* * *}\end{array}$ & $\begin{array}{c}0.067 \\
(0.042)\end{array}$ & $\begin{array}{c}0.060 \\
(0.026)^{* *}\end{array}$ & $\begin{array}{c}-0.002 \\
(0.036)\end{array}$ & $\begin{array}{l}1.630 \\
(2.198)\end{array}$ & $\begin{array}{c}-0.050 \\
(0.026)^{*}\end{array}$ \\
\hline $\mathrm{SMCR}_{t+2}$ years & $\begin{array}{l}-0.288 \\
(0.411)\end{array}$ & $\begin{array}{c}-0.057 \\
(0.054)\end{array}$ & $\begin{array}{c}-0.047 \\
(0.041)\end{array}$ & $\begin{array}{c}-0.013 \\
(0.043)\end{array}$ & $\begin{array}{c}-0.265 \\
(1.502)\end{array}$ & $\begin{array}{c}0.025 \\
(0.006)^{* * *}\end{array}$ \\
\hline $\begin{array}{l}\text { Bank Controls } \\
\text { Bank FE } \\
\text { Country-quarter FE }\end{array}$ & $\begin{array}{l}\text { yes } \\
\text { yes } \\
\text { yes }\end{array}$ & $\begin{array}{l}\text { yes } \\
\text { yes } \\
\text { yes }\end{array}$ & $\begin{array}{l}\text { yes } \\
\text { yes } \\
\text { yes }\end{array}$ & $\begin{array}{l}\text { yes } \\
\text { yes } \\
\text { yes }\end{array}$ & $\begin{array}{l}\text { yes } \\
\text { yes } \\
\text { yes }\end{array}$ & $\begin{array}{l}\text { yes } \\
\text { yes } \\
\text { yes }\end{array}$ \\
\hline $\begin{array}{l}\text { Obs. } \\
\text { N. clusters } \\
\text { R2 }\end{array}$ & $\begin{array}{c}3126 \\
137 \\
0.750\end{array}$ & $\begin{array}{c}3126 \\
137 \\
0.768\end{array}$ & $\begin{array}{c}3126 \\
137 \\
0.740\end{array}$ & $\begin{array}{c}3126 \\
137 \\
0.772\end{array}$ & $\begin{array}{c}3126 \\
137 \\
0.655\end{array}$ & $\begin{array}{c}3126 \\
137 \\
0.911\end{array}$ \\
\hline
\end{tabular}


Table 12: Impact on the Probability of Default

The table presents the baseline reduced form specification for the impact of the change in the SMCR on the probability of default as inferred from banks' ratings. Bank-level control variables are as specified in equation 1. Time period: 2010Q1-2017Q3. Standard errors are shown in parenthesis and are clustered at bank-level, robust to heteroscedasticity and serial correlation. FE stands for fixed-effects. Stars indicate statistical significance levels: ${ }^{* * *} \mathrm{p}<0.01,{ }^{* *} \mathrm{p}<0.05,{ }^{*} \mathrm{p}<0.10$.

\begin{tabular}{|c|c|c|c|c|c|}
\hline & \multicolumn{5}{|c|}{ Probability of Default Horizon } \\
\hline & $\begin{array}{l}\text { 5yrs } \\
\text { (p.p.) }\end{array}$ & $\begin{array}{l}\text { 4yrs } \\
\text { (p.p.) }\end{array}$ & $\begin{array}{l}\text { 3yrs } \\
\text { (p.p.) }\end{array}$ & $\begin{array}{l}2 y r s \\
\text { (p.p.) }\end{array}$ & $\begin{array}{c}1 \mathrm{yr} \\
(\text { p.p.) }\end{array}$ \\
\hline SMCR & $\begin{array}{c}1.346 \\
(1.044)\end{array}$ & $\begin{array}{c}1.293 \\
(1.042)\end{array}$ & $\begin{array}{c}1.161 \\
(1.028)\end{array}$ & $\begin{array}{c}0.930 \\
(0.981)\end{array}$ & $\begin{array}{c}0.533 \\
(0.776)\end{array}$ \\
\hline $\begin{array}{l}\text { SMCR } \times \\
>20 \text { bln. }<\text { Tot.Ass }<100 \text { bln. }\end{array}$ & $\begin{array}{c}-1.843 \\
(0.833)^{* *}\end{array}$ & $\begin{array}{c}-1.840 \\
(0.835)^{* *}\end{array}$ & $\begin{array}{c}-1.811 \\
(0.831)^{* *}\end{array}$ & $\begin{array}{c}-1.717 \\
(0.803)^{* *}\end{array}$ & $\begin{array}{c}-1.345 \\
(0.654)^{* *}\end{array}$ \\
\hline $\begin{array}{l}\text { SMCR } \times \\
\text { Tot.Ass > 100bln. }\end{array}$ & $\begin{array}{c}-2.011 \\
(0.893)^{* *}\end{array}$ & $\begin{array}{c}-1.999 \\
(0.895)^{* *}\end{array}$ & $\begin{array}{c}-1.960 \\
(0.888)^{* *}\end{array}$ & $\begin{array}{c}-1.868 \\
(0.858)^{* *}\end{array}$ & $\begin{array}{c}-1.471 \\
(0.699)^{* *}\end{array}$ \\
\hline $\begin{array}{l}\text { Bank Controls } \\
\text { Bank FE } \\
\text { Country-quarter FE }\end{array}$ & $\begin{array}{l}\text { yes } \\
\text { yes } \\
\text { yes }\end{array}$ & $\begin{array}{l}\text { yes } \\
\text { yes } \\
\text { yes }\end{array}$ & $\begin{array}{l}\text { yes } \\
\text { yes } \\
\text { yes }\end{array}$ & $\begin{array}{l}\text { yes } \\
\text { yes } \\
\text { yes }\end{array}$ & $\begin{array}{l}\text { yes } \\
\text { yes } \\
\text { yes }\end{array}$ \\
\hline $\begin{array}{l}\text { Obs. } \\
\text { N. clusters } \\
\text { R2 }\end{array}$ & $\begin{array}{c}1969 \\
87 \\
0.451\end{array}$ & $\begin{array}{c}1969 \\
87 \\
0.451\end{array}$ & $\begin{array}{c}1969 \\
87 \\
0.446\end{array}$ & $\begin{array}{c}1969 \\
87 \\
0.433\end{array}$ & $\begin{array}{c}1969 \\
87 \\
0.396\end{array}$ \\
\hline & & & rginal Effe & & \\
\hline $\begin{array}{l}\text { SMCR } \times \\
>20 \text { bln. }<\text { Tot.Ass }<100 \text { bln. }\end{array}$ & $\begin{array}{l}-0.497 \\
(1.100)\end{array}$ & $\begin{array}{l}-0.548 \\
(1.101)\end{array}$ & $\begin{array}{l}-0.650 \\
(1.094)\end{array}$ & $\begin{array}{l}-0.787 \\
(1.052)\end{array}$ & $\begin{array}{l}-0.811 \\
(0.840)\end{array}$ \\
\hline $\begin{array}{l}\text { SMCR } \times \\
\text { Tot.Ass }>100 \text { bln. }\end{array}$ & $\begin{array}{l}-0.665 \\
(1.183)\end{array}$ & $\begin{array}{l}-0.706 \\
(1.182)\end{array}$ & $\begin{array}{l}-0.799 \\
(1.172)\end{array}$ & $\begin{array}{l}-0.938 \\
(1.126)\end{array}$ & $\begin{array}{l}-0.938 \\
(0.900)\end{array}$ \\
\hline
\end{tabular}




\section{Appendix A: List of Banks}

Table A-I: List of GSIBs and O-SIBs with more than USD 300 billions in total assets as of 2016Q4

\begin{tabular}{|c|c|c|c|c|c|c|}
\hline Number & Country & GSI-OSI & Bank Name & Euro Area & Total Assets & IRB \\
\hline 1 & UK & GSI & HSBC Holdings Plc & No & 2251961725 & 1 \\
\hline 2 & $\mathrm{FR}$ & GSI & BNP Paribas SA & Yes & 2076959000 & 1 \\
\hline 3 & $\mathrm{DE}$ & GSI & Deutsche Bank AG & Yes & 1590546000 & 1 \\
\hline 4 & $\mathrm{FR}$ & GSI & Credit Agricole SA & Yes & 1524232000 & 1 \\
\hline 5 & UK & GSI & Barclays Bank Plc & No & 1421778818 & 1 \\
\hline 6 & FR & GSI & Societe Generale SA & Yes & 1382241000 & 1 \\
\hline 7 & ES & GSI & Banco Santander, SA & Yes & 1339124751 & 1 \\
\hline 8 & UK & OSI & Lloyds Banking Group Plc & No & 957795606 & 1 \\
\hline 9 & UK & GSI & Royal Bank of Scotland Group Plc & No & 935382435 & 1 \\
\hline 10 & UK & OSI & Goldman Sachs International & No & 885924120 & 1 \\
\hline 11 & IT & GSI & UniCredit SpA & Yes & 859532774 & 1 \\
\hline 12 & NL & GSI & ING Groep N.V. & Yes & 845081000 & 1 \\
\hline 13 & FR & OSI & Credit Mutuel Group & Yes & 793522000 & 1 \\
\hline 14 & FR & GSI & BPCE SA & Yes & 765069000 & 1 \\
\hline 15 & ES & GSI & Banco Bilbao Vizcaya Argentaria, SA & Yes & 731855527 & 1 \\
\hline 16 & IT & OSI & Intesa Sanpaolo SpA & Yes & 725100000 & 1 \\
\hline 17 & $\mathrm{SE}$ & GSI & Nordea Bank AB (publ) & No & 615659000 & 1 \\
\hline 18 & UK & GSI & Standard Chartered Plc & No & 613193354 & 1 \\
\hline 19 & UK & OSI & J.P. Morgan Capital Holdings Ltd. & No & 555986552 & 0 \\
\hline 20 & UK & OSI & Nomura Europe Holdings plc & No & 548007616 & 1 \\
\hline 21 & $\mathrm{DE}$ & OSI & DZ BANK AG Deutsche Zentral-Genossenschaftsbank & Yes & 509447000 & 1 \\
\hline 22 & NL & OSI & Rabobank & Yes & 498468992 & 1 \\
\hline 23 & $\mathrm{DE}$ & OSI & Commerzbank AG & Yes & 480450000 & $\mathrm{n} / \mathrm{a}$ \\
\hline 24 & DK & OSI & Danske Bank A/S & No & 468501389 & 0 \\
\hline 25 & UK & OSI & Morgan Stanley \& Co. International Plc & No & 401416677 & 1 \\
\hline 26 & UK & OSI & Merrill Lynch International & No & 395201226 & 1 \\
\hline 27 & NL & OSI & ABN AMRO Group NV & Yes & 394482000 & 1 \\
\hline 28 & UK & OSI & Santander UK Plc & No & 355038592 & 0 \\
\hline 29 & $\mathrm{ES}$ & OSI & CaixaBank, SA & Yes & 347927262 & 1 \\
\hline 30 & UK & OSI & Citigroup Global Markets Ltd. & No & 327705506 & 1 \\
\hline 31 & UK & OSI & Credit Suisse International & No & 315163664 & 1 \\
\hline 32 & $\mathrm{DE}$ & OSI & UniCredit Bank AG & Yes & 302090000 & 1 \\
\hline
\end{tabular}


Table A-II: Banks with total assets between USD 100 and USD 300 billions in total assets as of 2016Q4

\begin{tabular}{|c|c|c|c|c|c|c|}
\hline Number & Country & GSI-OSI & Bank Name & Euro Area & Total Assets & IRB \\
\hline 33 & $\mathrm{BE}$ & OSI & BNP Paribas Fortis SA & Yes & 297790000 & 1 \\
\hline 34 & $\mathrm{BE}$ & OSI & KBC Group NV & Yes & 275200000 & 1 \\
\hline 35 & $\mathrm{SE}$ & OSI & Svenska Handelsbanken AB (publ) & No & 274321632 & 1 \\
\hline 36 & $\mathrm{SE}$ & OSI & Skandinaviska Enskilda Banken AB (publ.) & No & 273597716 & 1 \\
\hline 37 & UK & OSI & Nationwide Building Society & No & 263401902 & 1 \\
\hline 38 & $\mathrm{NO}$ & OSI & DNB Bank ASA & No & 258682038 & 1 \\
\hline 39 & $\mathrm{DE}$ & OSI & Landesbank Baden-Wurttemberg & Yes & 243620000 & 0 \\
\hline 40 & FI & OSI & Nordea Pankki Suomi Oyj & Yes & 238775000 & 1 \\
\hline 41 & FR & OSI & La Banque Postale, SA & Yes & 229577420 & 1 \\
\hline 42 & $\mathrm{SE}$ & OSI & Swedbank AB (publ) & No & 224900662 & 1 \\
\hline 43 & $\mathrm{ES}$ & OSI & Banco de Sabadell, SA & Yes & 212507719 & 1 \\
\hline 44 & $\mathrm{DE}$ & OSI & Bayerische Landesbank & Yes & 212150000 & 1 \\
\hline 45 & $\mathrm{AT}$ & OSI & Erste Group Bank AG & Yes & 208227070 & 1 \\
\hline 46 & $\mathrm{ES}$ & OSI & Bankia, SA & Yes & 190167459 & 1 \\
\hline 47 & DK & OSI & Nykredit Realkredit A/S & No & 188360510 & 1 \\
\hline 48 & $\mathrm{BE}$ & OSI & Belfius Banque SA & Yes & 176720926 & 1 \\
\hline 49 & $\mathrm{DE}$ & OSI & NORD/LB Norddeutsche Landesbank Girozentrale & Yes & 174797000 & 1 \\
\hline 50 & $\mathrm{DE}$ & OSI & Landesbank Hessen-Thuringen Girozentrale & Yes & 165164000 & 0 \\
\hline 51 & $\mathrm{DE}$ & OSI & ING-DiBa AG & Yes & 157553000 & 1 \\
\hline 52 & NL & OSI & NV Bank Nederlandse Gemeenten & Yes & 154000000 & 1 \\
\hline 53 & IT & OSI & Banca Monte dei Paschi di Siena SpA & Yes & 153178466 & 1 \\
\hline 54 & $\mathrm{BE}$ & OSI & ING Belgie NV & Yes & 150418720 & 0 \\
\hline 55 & $\mathrm{ES}$ & OSI & Banco Popular Espanol, SA & Yes & 147925728 & 1 \\
\hline 56 & $\mathrm{DE}$ & OSI & NRW.BANK & Yes & 142065678 & 1 \\
\hline 57 & $\mathrm{AT}$ & OSI & Raiffeisen Zentralbank osterreich AG & Yes & 134846575 & 0 \\
\hline 58 & FI & OSI & OP Financial Group & Yes & 133747000 & 1 \\
\hline 59 & $\mathrm{DE}$ & OSI & Volkswagen Financial Services AG & Yes & 130148000 & 1 \\
\hline 60 & $\mathrm{NL}$ & OSI & SNS REAAL NV & Yes & 124806000 & 1 \\
\hline 61 & $\mathrm{IE}$ & OSI & Governor and Company of the Bank of Ireland & Yes & 123129000 & 1 \\
\hline 62 & UK & OSI & Credit Suisse Securities (Europe) Ltd. & No & 112791235 & 1 \\
\hline 63 & $\mathrm{AT}$ & OSI & Raiffeisen Bank International AG & Yes & 111863845 & 0 \\
\hline 64 & DK & OSI & Nordea Bank Danmark A/S & No & 108970440 & 1 \\
\hline 65 & $\mathrm{AT}$ & OSI & UniCredit Bank Austria AG & Yes & 105785411 & 1 \\
\hline 66 & $\mathrm{DE}$ & OSI & Landesbank Berlin Holding AG & Yes & 102437000 & 1 \\
\hline
\end{tabular}


Table A-III: Banks with total assets between USD 20 and USD 100 billions in total assets as of 2016Q4

\begin{tabular}{|c|c|c|c|c|c|c|}
\hline Number & Country & GSI-OSI & Bank Name & Euro Area & Total Assets & IRB \\
\hline 67 & IE & OSI & Allied Irish Banks, Plc & Yes & 95622000 & 0 \\
\hline 68 & $\mathrm{DE}$ & OSI & Landwirtschaftliche Rentenbank & Yes & 95045800 & 1 \\
\hline 69 & PT & OSI & Caixa Geral de Depositos, SA & Yes & 93547313 & 1 \\
\hline 70 & DE & OSI & Westdeutsche Genossenschafts-Zentralbank AG & Yes & 89794496 & 1 \\
\hline 71 & $\mathrm{DE}$ & OSI & DekaBank Deutsche Girozentrale & Yes & 85954700 & 1 \\
\hline 72 & $\mathrm{DE}$ & OSI & HSH Nordbank AG & Yes & 84365000 & 1 \\
\hline 73 & GR & OSI & Piraeus Bank SA & Yes & 81500534 & 1 \\
\hline 74 & DK & OSI & Jyske Bank A/S & No & 78902758 & 1 \\
\hline 75 & GR & OSI & National Bank of Greece SA & Yes & 78531000 & 1 \\
\hline 76 & NO & OSI & Nordea Bank Norge ASA & No & 73744593 & 1 \\
\hline 77 & $\mathrm{PT}$ & OSI & Banco Comercial Portugus, SA & Yes & 71264811 & 0 \\
\hline 78 & GR & OSI & Eurobank Ergasias SA & Yes & 66393000 & $\mathrm{n} / \mathrm{a}$ \\
\hline 79 & GR & OSI & Alpha Bank AE & Yes & 64872266 & $\mathrm{n} / \mathrm{a}$ \\
\hline 80 & PL & OSI & Powszechna Kasa Oszczednosci Bank Polski SA & No & 64851280 & 1 \\
\hline 81 & $\mathrm{PT}$ & OSI & Novo Banco, SA & Yes & 52332672 & 1 \\
\hline 82 & $\mathrm{LU}$ & OSI & Deutsche Bank Luxembourg SA & Yes & 51787398 & 1 \\
\hline 83 & UK & OSI & UBS Ltd. & No & 47624329 & 1 \\
\hline 84 & IE & OSI & Citibank Europe Plc & Yes & 46729176 & 1 \\
\hline 85 & NO & OSI & Kommunalbanken AS & No & 46082260 & 1 \\
\hline 86 & $\mathrm{LU}$ & OSI & CACEIS Bank Luxembourg SA & Yes & 46081972 & 0 \\
\hline 87 & $\mathrm{PT}$ & OSI & Santander Totta, SGPS SA & Yes & 44991681 & 1 \\
\hline 88 & LU & OSI & BGL BNP Paribas SA & Yes & 44980200 & 0 \\
\hline 89 & LU & OSI & Banque et Caisse d'Epargne de l'Etat, Luxembourg & Yes & 43468625 & 0 \\
\hline 90 & LU & OSI & Societe Generale Bank \& Trust SA & Yes & 42187856 & 0 \\
\hline 91 & $\mathrm{CZ}$ & OSI & ceskoslovenska obchodn banka, a.s. & No & 40177083 & 0 \\
\hline 92 & AT & OSI & Bank fur Arbeit und Wirtschaft und Osterreichische Postsparkasse AG & Yes & 39743000 & 1 \\
\hline 93 & PL & OSI & Bank Polska Kasa Opieki SA & No & 39562822 & 1 \\
\hline 94 & $\mathrm{CZ}$ & OSI & ceska spoitelna, a.s. & No & 39473826 & 0 \\
\hline 95 & AT & OSI & Raiffeisenlandesbank Oberosterreich AG & Yes & 39385129 & 0 \\
\hline 96 & PT & OSI & Banco BPI, SA & Yes & 38284652 & 1 \\
\hline 97 & $\mathrm{BE}$ & OSI & Bank of New York Mellon SA/NV & Yes & 36427299 & 1 \\
\hline 98 & $\mathrm{HU}$ & OSI & OTP Bank Nyrt. & No & 36291787 & 1 \\
\hline 99 & $\mathrm{BE}$ & OSI & Argenta Spaarbank NV & Yes & 36156329 & 1 \\
\hline 100 & $\mathrm{CZ}$ & OSI & Komercn banka, a.s. & No & 34151966 & 0 \\
\hline 101 & PL & OSI & Bank Zachodni WBK SA & No & 34086447 & 1 \\
\hline 102 & FI & OSI & Kuntarahoitus Oyj & Yes & 34052186 & 0 \\
\hline 103 & IE & OSI & Ulster Bank Ireland DAC & Yes & 30694000 & 1 \\
\hline 104 & PL & OSI & mBank SA & No & 30372081 & 1 \\
\hline 105 & FI & OSI & Danske Bank Oyj & Yes & 28962100 & 1 \\
\hline 106 & $\mathrm{BE}$ & OSI & AXA Bank Belgium SA & Yes & 27994508 & 0 \\
\hline 107 & $\mathrm{IE}$ & OSI & DEPFA BANK Plc & Yes & 27596000 & 0 \\
\hline 108 & PL & OSI & ING Bank slaski SA & No & 26678248 & 1 \\
\hline 109 & AT & OSI & Raiffeisenlandesbank Niederosterreich-Wien AG & Yes & 25404784 & 1 \\
\hline 110 & $\mathrm{IE}$ & OSI & Permanent TSB Group Holdings Plc & Yes & 23601000 & 1 \\
\hline 111 & $\mathrm{CZ}$ & OSI & UniCredit Bank Czech Republic and Slovakia, a.s. & No & 23503916 & 0 \\
\hline 112 & $\mathrm{LU}$ & OSI & Banque Internationale a Luxembourg SA & Yes & 23148659 & 0 \\
\hline 113 & $\mathrm{CY}$ & OSI & Bank of Cyprus Public Company Ltd. & Yes & 22171935 & 1 \\
\hline 114 & PT & OSI & Caixa Economica Montepio Geral, caixa economica bancaria, SA & Yes & 21345909 & 0 \\
\hline 115 & DK & OSI & DLR Kredit A/S & No & 20944292 & 0 \\
\hline
\end{tabular}


Table A-IV: Banks with total assets lower than USD 20 billions in total assets as of 2016Q4

\begin{tabular}{|c|c|c|c|c|c|c|}
\hline Number & Country & GSI-OSI & Bank Name & Euro Area & Total Assets & IRB \\
\hline 116 & IE & OSI & UniCredit Bank Ireland Plc & Yes & 19987653 & 1 \\
\hline 117 & DK & OSI & Sydbank A/S & No & 19727068 & 1 \\
\hline 118 & $\mathrm{HR}$ & OSI & Zagrebacka banka d.d. & No & 16980269 & 0 \\
\hline 119 & PL & OSI & Bank BG BNP Paribas SA & No & 16419888 & 1 \\
\hline 120 & PL & OSI & Bank Millennium SA & No & 15622293 & 0 \\
\hline 121 & $\mathrm{AT}$ & OSI & HYPO NOE Landesbank fur Niederosterreich und Wien AG & Yes & 15392051 & 0 \\
\hline 122 & $\mathrm{PL}$ & OSI & Getin Noble Bank SA & No & 15105513 & 0 \\
\hline 123 & $\mathrm{BE}$ & OSI & Euroclear Bank SA/NV & Yes & 14885444 & 1 \\
\hline 124 & RO & OSI & Banca Comerciala Romana SA & No & 14873912 & 0 \\
\hline 125 & SK & OSI & Slovenska Sporitelna, a.s. & Yes & 14825374 & 0 \\
\hline 126 & $\mathrm{CY}$ & OSI & Cyprus Cooperative Bank Ltd. & Yes & 14100791 & 1 \\
\hline 127 & SK & OSI & Vseobecna uverova banka, a.s. & Yes & 14037154 & 0 \\
\hline 128 & $\mathrm{AT}$ & OSI & Sberbank Europe AG & Yes & 12709542 & 0 \\
\hline 129 & PL & OSI & Raiffeisen Bank Polska SA & No & 12094460 & 1 \\
\hline 130 & SI & OSI & Nova Ljubljanska banka d.d., Ljubljana & Yes & 12039011 & 0 \\
\hline 131 & $\mathrm{CZ}$ & OSI & Raiffeisenbank a.s. & No & 11984202 & 1 \\
\hline 132 & RO & OSI & Banca Transilvania SA & No & 11443660 & 1 \\
\hline 133 & RO & OSI & BRD-Groupe Societe Generale SA & No & 11429840 & 1 \\
\hline 134 & SK & OSI & Tatra banka, a.s. & Yes & 11373028 & 0 \\
\hline 135 & MT & OSI & Bank of Valletta Plc & Yes & 11014330 & 0 \\
\hline 136 & $\mathrm{HR}$ & OSI & Privredna Banka Zagreb d.d. & No & 10867118 & 1 \\
\hline 137 & BG & OSI & UniCredit Bulbank AD & No & 10424208 & 1 \\
\hline 138 & PL & OSI & Bank Handlowy w Warszawie SA & No & 10266811 & 1 \\
\hline 139 & $\mathrm{EE}$ & OSI & Swedbank AS & Yes & 10233000 & 1 \\
\hline 140 & $\mathrm{HU}$ & OSI & K\&H Bank Zrt. & No & 9148828 & 1 \\
\hline 141 & $\mathrm{HU}$ & OSI & UniCredit Bank Hungary Zrt. & No & 8861671 & 1 \\
\hline 142 & $\mathrm{AT}$ & OSI & Oberosterreichische Landesbank AG & Yes & 8756780 & 1 \\
\hline 143 & $\mathrm{CY}$ & OSI & RCB Bank Ltd. & Yes & 8699021 & 0 \\
\hline 144 & HR & OSI & Erste\&Steiermarkische Bank d.d. & No & 8680694 & 0 \\
\hline 145 & SK & OSI & Ceskoslovenska obchodna banka, a.s. & Yes & 8543773 & 0 \\
\hline 146 & RO & OSI & UniCredit Bank SA & No & 8284788 & 0 \\
\hline 147 & AT & OSI & Hypo Tirol Bank AG & Yes & 7632172 & 1 \\
\hline 148 & LT & OSI & AB SEB bankas & Yes & 7517939 & 1 \\
\hline 149 & $\mathrm{RO}$ & OSI & Raiffeisen Bank SA & No & 7371604 & 0 \\
\hline 150 & $\mathrm{LT}$ & OSI & Swedbank, AB & Yes & 7324953 & 0 \\
\hline 151 & MT & OSI & HSBC Bank Malta Plc & Yes & 7305964 & 1 \\
\hline 152 & $\mathrm{CY}$ & OSI & Hellenic Bank Public Company Ltd. & Yes & 7037604 & 0 \\
\hline 153 & HU & OSI & MKB Bank Zrt. & No & 6804454 & 1 \\
\hline 154 & $\mathrm{HU}$ & OSI & Magyar Takarekszovetkezeti Bank Zrt. & No & 6776778 & 0 \\
\hline 155 & $\mathrm{HU}$ & OSI & Erste Bank Hungary Zrt. & No & 6627237 & 1 \\
\hline 156 & $\mathrm{HU}$ & OSI & Raiffeisen Bank Zrt. & No & 6457088 & $\mathrm{n} / \mathrm{a}$ \\
\hline 157 & RO & OSI & CEC Bank SA & No & 6204473 & 0 \\
\hline 158 & $\mathrm{BG}$ & OSI & DSK Bank EAD & No & 6050100 & 0 \\
\hline 159 & $\mathrm{EE}$ & OSI & AS SEB Pank & Yes & 5775400 & 0 \\
\hline
\end{tabular}


Table A-IV: Ctd. Banks with total assets lower than USD 20 billions in total assets as of 2016Q4

\begin{tabular}{|c|c|c|c|c|c|c|}
\hline Number & Country & GSI-OSI & Bank Name & Euro Area & Total Assets & IRB \\
\hline 160 & $\mathrm{HU}$ & OSI & CIB Bank Zrt. & No & 5277329 & 0 \\
\hline 161 & $\mathrm{LV}$ & OSI & Swedbank AS & Yes & 5242209 & 0 \\
\hline 162 & $\mathrm{CZ}$ & OSI & PPF banka a.s. & No & 5063556 & 0 \\
\hline 163 & $\mathrm{CZ}$ & OSI & J\&T Banka, a.s. & No & 4926761 & 0 \\
\hline 164 & $\mathrm{CY}$ & OSI & Eurobank Cyprus Ltd. & Yes & 4879262 & $\mathrm{n} / \mathrm{a}$ \\
\hline 165 & SI & OSI & Nova Kreditna banka Maribor d.d. & Yes & 4823450 & 0 \\
\hline 166 & HR & OSI & Raiffeisenbank Austria d.d. & No & 4679339 & 0 \\
\hline 167 & BG & OSI & First Investment Bank AD & No & 4647865 & 1 \\
\hline 168 & $\mathrm{PL}$ & OSI & Bank Polskiej Spoldzielczosci SA & No & 4578087 & 0 \\
\hline 169 & SK & OSI & Postova banka, a.s. & Yes & 4261460 & 0 \\
\hline 170 & $\mathrm{LT}$ & OSI & Luminor Bank AB & Yes & 3988565 & $\mathrm{n} / \mathrm{a}$ \\
\hline 171 & $\mathrm{LV}$ & OSI & ABLV Bank, AS & Yes & 3973323 & 0 \\
\hline 172 & $\mathrm{PL}$ & OSI & SGB-Bank SA & No & 3947797 & 1 \\
\hline 173 & SI & OSI & Abanka d.d. & Yes & 3614833 & 0 \\
\hline 174 & $\mathrm{HR}$ & OSI & Splitska banka d.d. & No & 3577384 & 0 \\
\hline 175 & $\mathrm{LV}$ & OSI & AS SEB banka & Yes & 3523911 & 0 \\
\hline 176 & BG & OSI & United Bulgarian Bank AD & No & 3495997 & 0 \\
\hline 177 & BG & OSI & Eurobank Bulgaria AD & No & 3486344 & 0 \\
\hline 178 & $\mathrm{LV}$ & OSI & JSC "Rietumu Banka" & Yes & 3473590 & 1 \\
\hline 179 & $\mathrm{LV}$ & OSI & AS Citadele banka & Yes & 3349515 & 0 \\
\hline 180 & BG & OSI & Raiffeisenbank (Bulgaria) EAD & No & 3329009 & 0 \\
\hline 181 & BG & OSI & Societe Generale Expressbank AD & No & 3246381 & 0 \\
\hline 182 & $\mathrm{RO}$ & OSI & Alpha Bank Romania SA & No & 3245660 & 1 \\
\hline 183 & SI & OSI & SKB banka d.d., Ljubljana & Yes & 2955262 & 0 \\
\hline 184 & HR & OSI & Addiko Bank d.d. & No & 2777215 & 0 \\
\hline 185 & BG & OSI & Central Cooperative Bank AD & No & 2651696 & 0 \\
\hline 186 & SI & OSI & UniCredit Banka Slovenija d.d. & Yes & 2642950 & 0 \\
\hline 187 & $\mathrm{HR}$ & OSI & Hrvatska postanska banka, d.d. & No & 2611695 & 1 \\
\hline 188 & $\mathrm{CY}$ & OSI & Alpha Bank Cyprus Ltd. & Yes & 2596415 & 0 \\
\hline 189 & SI & OSI & SID - Slovenska izvozna in razvojna banka, d.d., Ljubljana & Yes & 2596076 & 0 \\
\hline 190 & $\mathrm{RO}$ & OSI & SC Bancpost SA & No & 2564081 & $\mathrm{n} / \mathrm{a}$ \\
\hline 191 & MT & OSI & MeDirect Group Ltd. & Yes & 2489506 & 0 \\
\hline 192 & SI & OSI & Banka Intesa Sanpaolo d.d. & Yes & 2325663 & 0 \\
\hline 193 & $\mathrm{LV}$ & OSI & Luminor Bank AS & Yes & 2259247 & 0 \\
\hline 194 & RO & OSI & Garanti Bank SA & No & 1973878 & 0 \\
\hline 195 & $\mathrm{HU}$ & OSI & FHB Jelzalogbank Nyrt. & No & 1921279 & 0 \\
\hline 196 & $\mathrm{LT}$ & OSI & siauliu bankas $\mathrm{AB}$ & Yes & 1861278 & 0 \\
\hline 197 & SI & OSI & Sberbank banka d. d. & Yes & 1846119 & $\mathrm{n} / \mathrm{a}$ \\
\hline 198 & $\mathrm{RO}$ & OSI & OTP Bank Romania SA & No & 1808437 & 1 \\
\hline 199 & $\mathrm{CY}$ & OSI & Alfa Capital Holdings (Cyprus) Ltd. & Yes & 1803745 & 1 \\
\hline 200 & $\mathrm{HR}$ & OSI & OTP banka Hrvatska d.d. & No & 1694090 & $\mathrm{n} / \mathrm{a}$ \\
\hline 201 & $\mathrm{BG}$ & OSI & CIBANK EAD & No & 1584441 & 1 \\
\hline 202 & $\mathrm{BG}$ & OSI & Piraeus Bank Bulgaria AD & No & 1508035 & 1 \\
\hline 203 & $\mathrm{RO}$ & OSI & Piraeus Bank Romania SA & No & 1446053 & 1 \\
\hline 204 & $\mathrm{RO}$ & OSI & Banca Romaneasca SA & No & 1418917 & $\mathrm{n} / \mathrm{a}$ \\
\hline 205 & HR & OSI & Sberbank d.d. & No & 1225733 & $\mathrm{n} / \mathrm{a}$ \\
\hline
\end{tabular}

